\title{
Stratigraphy of the upper Vijlen Member (Gulpen Formation; Maastrichtian) in northeast Belgium, the southeast Netherlands and the Aachen area (Germany), with special reference to belemnitellid cephalopods
}

\author{
N. Keutgen ${ }^{1,2}$, J.W.M. Jagt ${ }^{1,}{ }^{*}$, P.J. Felder ${ }^{3}$ \& E.A. Jagt-Yazykova ${ }^{4}$ \\ 1 Natuurhistorisch Museum Maastricht, de Bosquetplein 6-7, NL-6211 KJ Maastricht, the Netherlands. \\ 2 Uniwersytet Techniczno-Przyrodniczy Bydgoszcz, ul. Bernardynska 6/8, PL-85 029 Bydgoszcz, Poland. \\ 3 Deceased. \\ 4 Uniwersytet Opolski, Wydział Przyrodniczo-Techniczny, Katedra Biosystematyki, ul. Oleska 22, PL- 45052 Opole, Poland. \\ * Corresponding author. Email: john.jagt@maastricht.nl.
}

Manuscript received: October 2009, accepted: March 2010

\begin{abstract}
Recent studies have demonstrated the complex depositional history of the Vijlen Member (Gulpen Formation) in the Maastricht-Aachen-Liège area, on which synsedimentary tectonics had a profound impact, in conjunction with regressive and transgressive episodes, the oldest portion of this member being preserved only locally, within channel-like structures. Our reinterpretation of the Vijlen Member, here presented, is at variance with current belemnite stratigraphy. To account for incongruities, reworking of belemnites is here proposed as a typical feature during Vijlen Member deposition. A renewed study of belemnites on the basis of these new data suggests that intervals 4-6 of the Vijlen Member are of late Maastrichtian age. With respect to the mean values of populations of Belemnitella junior Nowak and Belemnitella lwowensis Naidin, Vijlen Member intervals 4-5 are coeval with the Spyridoceramus tegulatus/Belemnitella junior Zone (sensu germanico), whereas at least the upper portion of interval 6 is correlatable with the basal Tenuipteria argentea/Belemnitella junior Zone (sensu germanico). Although reworking of belemnites appears to have been a common feature, this cannot be properly substantiated without additional geochemical analyses of individual guards. For this reason, we refrain from proposing a biostratigraphic zonation of the Vijlen Member based on belemnites. Alternatively, scaphitid ammonites might be used to subdivide this member, because species such as Acanthoscaphites (Acanthoscaphites) tridens (Kner), A. (Euroscaphites) varians blaszkiewiczi Jagt, Kennedy \& Machalski, Hoploscaphites constrictus (J. Sowerby), H. tenuistriatus (Kner) and Hoploscaphites sp. have been recorded. The last-named taxon represents an interspecies hybrid between the North American Jeletzkytes dorfi Landman \& Waage and an unidentified subspecies of the endemic European lineage of H. constrictus, allowing correlation of the lower portion of Vijlen Member interval 6 with the Hoploscaphites birkelundae Zone of the United States Western Interior.
\end{abstract}

Keywords: Coleoidea, Belemnitellidae, Vijlen Member, Maastrichtian type area, Netherlands, Belgium, Germany, correlation

\section{Introduction}

As noted by Albers \& Felder (1979), the Maastrichtian age of the Vijlen Member (Gulpen Formation; sensu Felder (1975a, 1975b) in the extended type area of the Maastrichtian Stage (Fig. 1) has never been in doubt. However, specific assignments and correlations between sections exposing portions of this unit have varied considerably. Using belemnites, Keutgen \& Van der Tuuk (1991) identified relicts of the early Maastrichtian Belemnella obtusa, sumensis and cimbrica zones (sensu Schulz,
1979), in addition to the late Maastrichtian Belemnitella junior Zone. A more detailed biozonation was subsequently proposed by Keutgen (1996), who attempted to correlate these biozones with the seven intervals (0 to 6) distinguished by Felder \& Bless (1994) in the combined type section of the Vijlen Member at Mamelis, just west of Vaals (Netherlands/Germany border). However, subsequent correlation of sections on the basis of bioclast (eco-)stratigraphy (Felder, 2001) proved to be in conflict with belemnite stratigraphy (Keutgen \& Van der Tuuk, 1991; Keutgen, 1997) and with Keutgen's (1996) biozonation. 


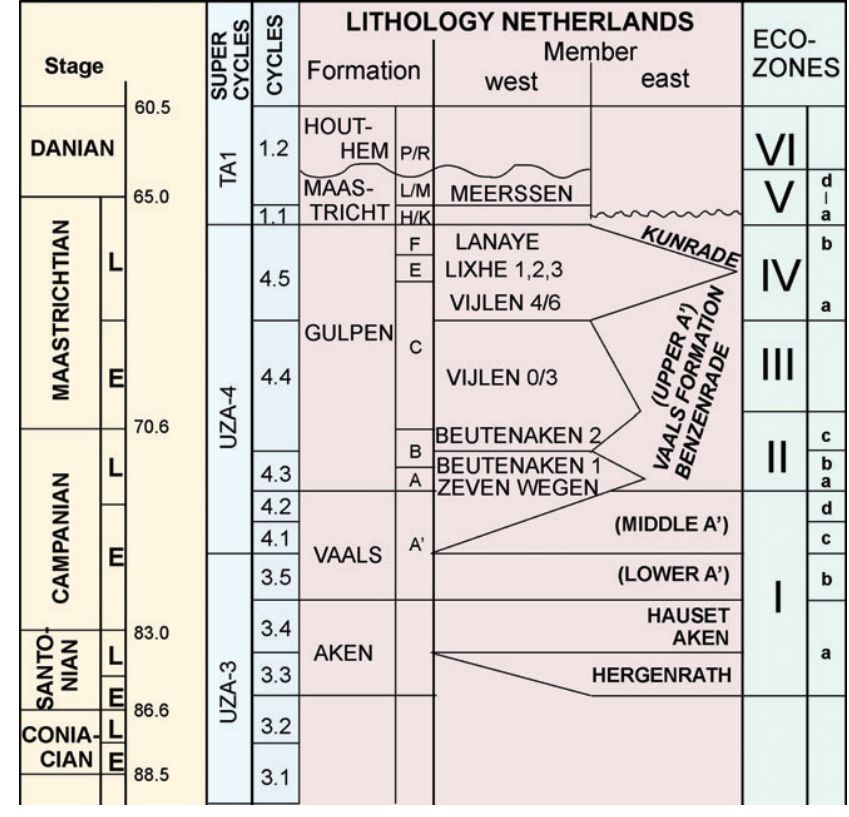

Fig. 1. Chrono- and lithostratigraphy of Upper Cretaceous and lower Paleocene strata exposed in the extended type area of the Maastrichtian Stage, correlated with sequence-stratigraphic units, and subdivided into foraminiferal zones ( $A^{\prime}-R$; see Hofker, 1966) and bioclast ecozones (I-VI) (modified after Felder, 2001).

For example, Felder (2001, fig. 38) identified relicts of intervals 0-5 within the lower c. $0.8 \mathrm{~m}$ of this member at the Bovenste Bos quarry (Netherlands) and correlated the overlying portion with interval 6, whereas Keutgen (1996) had equated the lower c. $2 \mathrm{~m}$ at that locality with interval 0 , on account of the occurrence of early forms of Belemnella (Pachybelemnella) sumensis Jeletzky, 1949 (see Keutgen \& Van der Tuuk, 1991). Similarly, Felder (2001, fig. 18) correlated the lower c. $5 \mathrm{~m}$ of the Vijlen Member at the CPL SA quarry (Haccourt, also referred to as Halembaye or Hallembaye), which are of late Maastrichtian age (Keutgen \& Van der Tuuk, 1991), with interval 5 as documented at the Mamelis type section of this member, although that interval yielded the typically late early Maastrichtian Belemnella (Pachybelemnella) cf. cimbrica Birkelund, 1957 (Felder \& Bless, 1994), which is also known from the Wilkensberg nearby (Keutgen \& Van der Tuuk, 1991). The most notable difference in interpretation of the stratigraphy of Vijlen Member strata using either belemnites or bioclasts, however, was observed at Altembroeck (Voer, northeast Belgium). Keutgen (1997) proposed correlation of the entire Vijlen Member there with interval 0 (of the Mamelis section), on account of the occurrence of early forms of $B l n$. (P.) cf. sumensis and Belemnella (Bln.) cf. praearkhangelskii Naidin, 1964 at about 4.3-4.5 m below the top of the Vijlen Member exposed there. In contrast, Felder (2001, fig. 40) equated the entire Altembroeck section (c. $12 \mathrm{~m}$ thick) with intervals 2-4 of the Mamelis section. Most of the macrofossil taxa listed by Jagt et al. (1995), plus belemnites studied by
Keutgen (1997), come from interval 4 sensu Felder (2001) and some of these actually place in question the age assignment based on belemnites. For instance, the galeritid echinoid Galerites stadensis (Lambert, 1911) (sensu Schulz, 1985) was found to co-occur with early forms of Bln. (P.) cf. sumensis and $B l n$. (Bln.) cf. praearkhangelskii, indicative of the middle Bln. sumensis Zone, although in northern Germany the first appearance datum (FAD) of that echinoid is slightly later in the upper Bln. sumensis Zone; it ranges into the uppermost Maastrichtian (Schulz, 1985). From the same level at Altembroeck, Jäger (2004) recorded the serpulid Conorca trochiformis (Von Hagenow, 1840) which displayed morphological features favouring a Bln. cimbrica Zone dating.

The belemnite biostratigraphy of Keutgen \& Van der Tuuk (1991) and Keutgen (1996, 1997) was based mainly on the succession, and disappearance, of species of the genus Belemnella Nowak, 1913. The genus Belemnitella d'Orbigny, 1840 received less attention, because at that time the late Maastrichtian Belemnitella fauna from northwest Europe was still poorly understood. Recently, Christensen et al. (2004) have re-evaluated Belemnitella from the upper Maastrichtian at Hemmoor (northern Germany) and this work now enables a reinterpretation of members of this genus in the Vijlen Member and a comparison of these results with current bioclast data.

Abbreviations - To denote the repositories of material illustrated and/or referred to in the text, the following abbreviations are used: NHM, The Natural History Museum, Department of Palaeontology, London (formerly British Museum of Natural History); NHMM, Natuurhistorisch Museum Maastricht, Maastricht. Schulz (1979) distinguished between early, typical and late forms of his species of Belemnella (Pachybelemnella). The following abbreviations were used: f.a., forma anterior; f.m., forma media; f.p., forma posterior.

\section{Current views on Vijlen Member stratigraphy}

In the Netherlands/Belgium/Germany borderland, commonly referred to as the Maastricht-Aachen-Liège area, Vijlen Member strata are known from a relatively limited area between the Roer Valley Graben and the Brabant Massif (Felder, 1997; see Fig. 2 here). Amongst the most striking features of this unit are marked differences in thickness. In two narrow strips, more or less parallel to the Roer Valley Graben, this unit may reach thicknesses in excess of 70 metres, whereas beyond these strips, the magnitude generally varies between 0 and $30 \mathrm{~m}$. These strips have been identified as part of a channel system (Fig. 2) running from Aachen to Gulpen and from Altembroeck to Lanaye ('0ost Maarland borehole'), possibly extending into the western Campine area, Belgium (Felder, 1997). This channel system developed during the late Campanian, early Maastrichtian or earliest late Maastrichtian, prior to the onset of sedimentation of the Vijlen Member and was eroded in an otherwise fairly flat, nearshore area. 


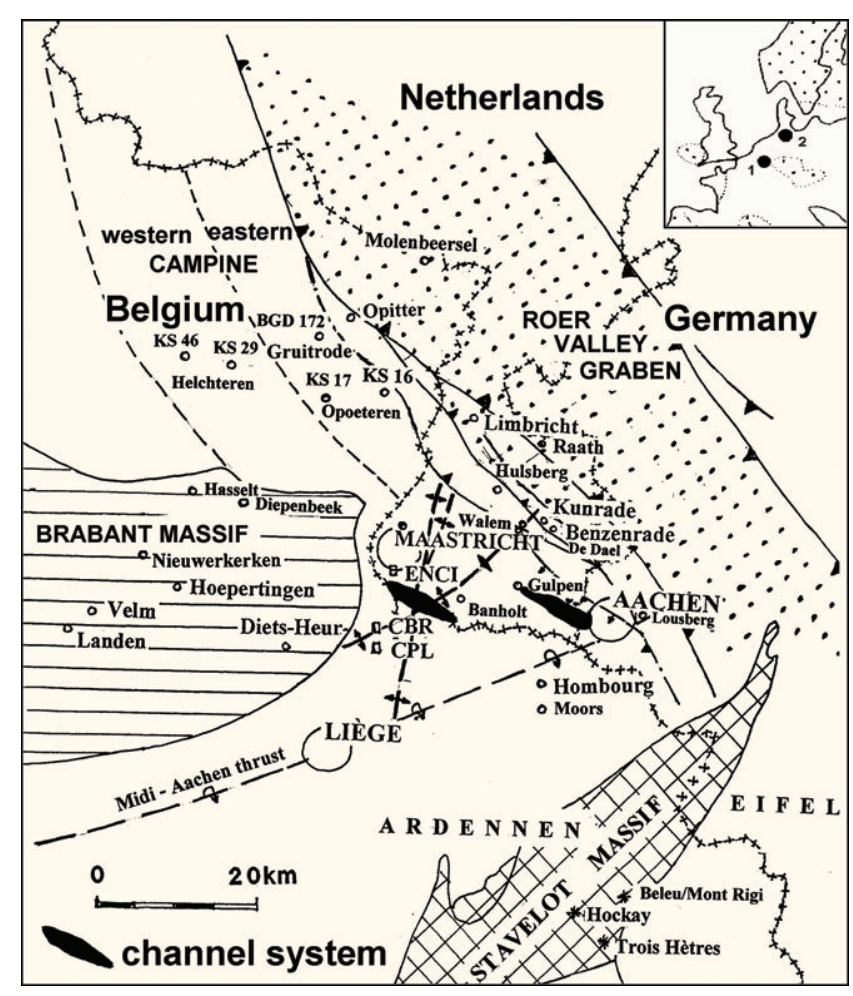

Fig. 2. The Maastricht-Aachen-Liège area and adjacent regions (1), compared (inset) to Kronsmoor/Hemmoor, northern Germany (2). Channel systems, extending between Aachen and Gulpen and between Altembroeck and Lanaye, are indicated (after Felder, 1997).

The combined type section (Fig. 3) at Mamelis, where the Vijlen Member is completely developed, comprises the Mamelis sunken road section (locality 62D-79, co-ordinates 312.330/ 196.450) and the Mamelis borehole (locality 62D-68). At Mamelis, the Vijlen Member was subdivided by Felder \& Bless (1994) into seven intervals, numbered $0-6$, as based on bioclasts, benthic foraminifera and ostracods, as well as on lithological characteristics. Subsequent research on the bioclasts has revealed that especially benthic foraminifera in the 1-2.4 mm sieve fraction were suitable for further subdivision. At Mamelis, thirteen major foraminifer peaks, labelled A (base) to L (top) have been distinguished (Felder, 1997, 2001). Additional data derive from bivalve bioclasts; the boundaries between the seven intervals are defined either by peaks in foraminiferal or bivalve distribution.

Interpretation of the oldest Vijlen Member deposits as channel infill has allowed the conclusion that at least part of the material filling up the channel system, namely glauconite and quartz grains, had been eroded from the channel margins. Glauconite, for example, may have originated from Vaals Formation strata (Felder \& Bless, 1994), as may some of the reworked fossils (Keutgen, 1996). However, remanié fossils of late Campanian and early Maastrichtian age may also be expected within these channel deposits, having been derived from deposits that are no longer preserved. This represents a serious problem for belemnite stratigraphy, because belemnites are considered to be comparatively resistent to reworking processes (Doyle \& Macdonald, 1993).

For the present study, correlation of deposits with the Vijlen Member type section at Mamelis is based on results of bioclast stratigraphy (Felder, 1997, 2001). For localities from which bioclast samples have been studied, correlation with the seven lithological intervals exposed at the extended type section at Mamelis has proved possible, viz. for sections exposed at Altembroeck, Pesaken-Crapoel, Beutenaken, the Bovenste Bos quarry and the CPL SA quarry (Haccourt) (Fig. 4 here; see also Felder, 2001). For the localities Wilkensberg (Ebensberger, 1962) and Hans-Böckler-Allee (Felder \& Bless, 1994), foraminiferal assemblages documented allow a rough match with the type section at Mamelis, while the locality Schurzelterstraße can be assigned to a level slightly below strata formerly exposed at the Hans-Böckler-Allee due to the proximity of both sections. Only the localities Lemierserberg and Vaalserstraße are difficult to date, but the documented faunal content allows at least a rough correlation with the type section of the Vijlen Member (Fig. 4).

Due to the inadequate exposure of Vijlen Member deposits at the type locality near Mamelis, a subdivision of this member is possible only by using foraminifera, ostracods, bioclasts and lithological characteristics. However, the lithology of the Vijlen Member can change considerably within a limited area so that beds extending over large distances were not encountered (Felder \& Bless, 1994; Felder, 1997). Biostratigraphic subdivision of the Vijlen Member is still based mainly on foraminiferal and ostracod assemblages. Felder \& Bless (1994) distinguished the foraminiferal assemblage zones C and D of Hofker (1966), with Zone $\mathrm{D}$ being restricted to the uppermost $7 \mathrm{~m}$ of the Vijlen Member. However, these authors also indicated that Zone $\mathrm{C}$ may be separated into a lower portion, where Bolivinoides draco miliaris Hiltermann \& Koch, 1950 and Neoflabellina permutata Koch, 1977 occur, and an upper portion with Nonionella troostae (Visser, 1951). At Mamelis, the boundary between subzones $\mathrm{C}_{\text {upper }}$ and $\mathrm{C}_{\text {lower }}$ corresponds roughly to the base of interval 4 of the Vijlen Member and this level is also characterised by a distinct change in macrofauna. While well-preserved specimens of Acanthoscaphites (A.) tridens (Kner, 1848) are known exclusively from deposits below the base of interval 4 (Jagt et al., 1999), Diplodetus duponti (Lambert, 1911) and Hoploscaphites constrictus (J. Sowerby, 1817) first occur frequently above this level (Van der Ham \& Van Birgelen, 1992; Jagt et al., 1995; Keutgen, 1996). Belemnitella junior Nowak, 1913 and Blt. lwowensis Naidin, 1952 first appear close to the base of interval 4 as well (see hereafter). The FAD of Acanthoscaphites (Euroscaphites) varians blaszkiewiczi Jagt, Kennedy \& Machalski, 1999 is close to the base of interval 6 of the Vijlen Member (Jagt \& Kennedy, 1989). In summary, a subdivision of the Vijlen Member into three portions appears possible, using either foraminifera or scaphitid ammonites. 
Fig. 3. Lithology and bioclast contents for the Vijlen Member in its type area near Mamelis (modified after Felder, 2001, fig. 22).

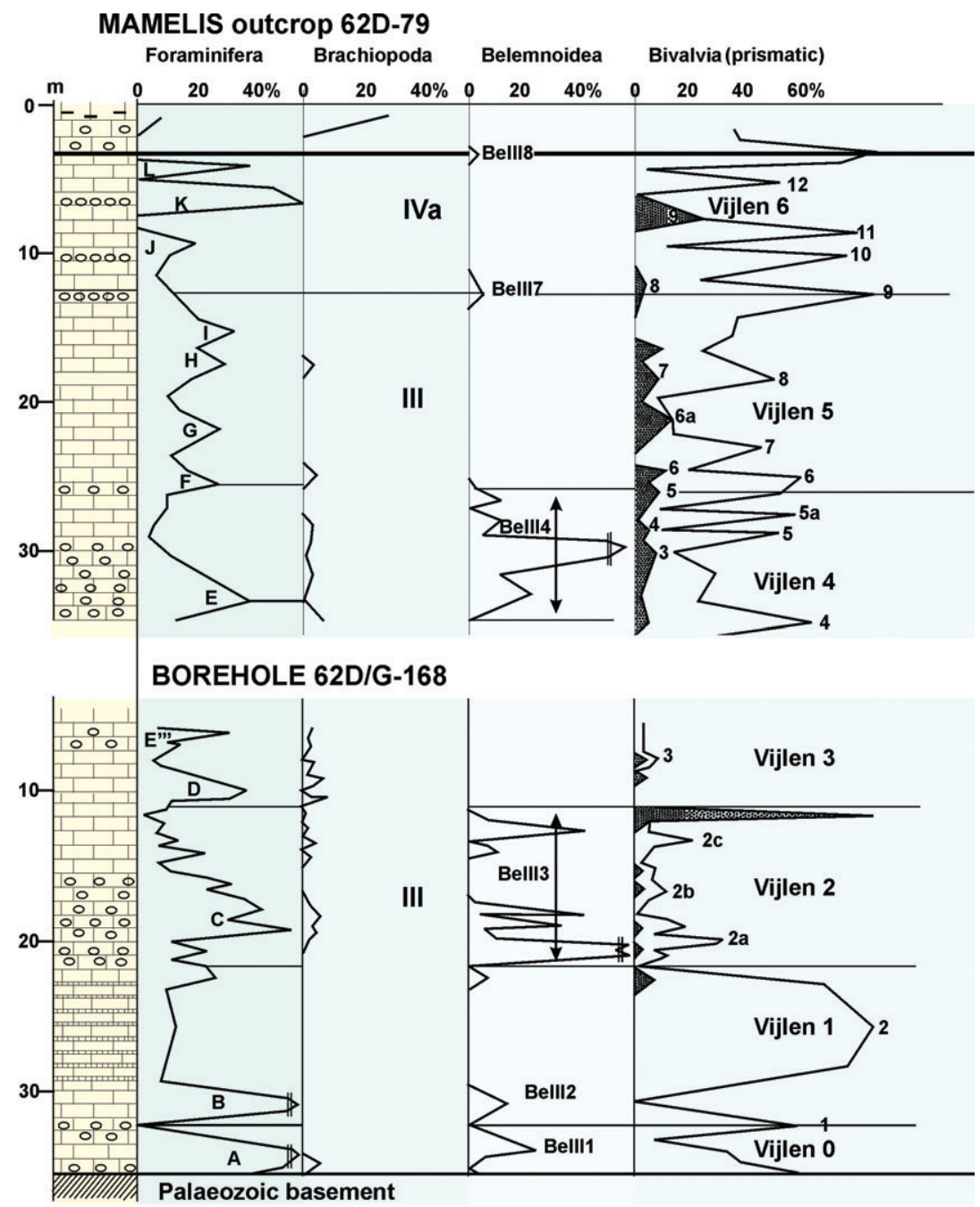

\section{Comments on previous identifications of material of Belemnella}

The present study has made it clear that several so-called 'populations' of the genus Belemnella as described by Keutgen \& Van der Tuuk (1991) and Keutgen (1997) actually consisted of reworked specimens. This conclusion was based on strictly biostratigraphical arguments, referring to anomalies in the expected biostratigraphic zonations of belemnites. Here, deposits have been dated with respect to the stratigraphically youngest belemnite species or stratigraphic forma(e); documenting evidence for reworking (e.g. sedimentological evidence for downslope transport or fossil preservational state) was beyond the scope of the investigation. In future studies, it would be worthwhile to document whether or not isotopic and elemental composition (Nieto et al., 2008) might be the key to distinguish between remanié and indigenous belemnite rostra in the study area. Seen in this light, the lack of isotopic continuity between belemnite rostra on the one hand and inoceramid shells and chalk matrix on the other (as documented for the Altembroeck section; see Elorza et al., 1997), might be re-interpreted in terms of belemnite reworking.
The realisation that strata assigned to the Vijlen Member contained remanie specimens of the genus Belemnella, posed the question of how to identify samples of reworked belemnites that may even have originated from different belemnite zones. The identification key provided by Schulz (1979) applies only to populations, while single specimens might easily fall into the range of variation of several populations, as described by Schulz (1979), and be referred to different species. In order to obtain a picture of the species of Belemnella that do occur, the range of variation of populations described by Schulz (1979) was taken as a basis. Schulz (1979) distinguished the subgenera Belemnella (Belemnella) Nowak (1913) and Belemnella (Pachybelemnella) Schulz (1979) on the Lsn value (see hereafter). Distinguishing between the subgenera did not present a problem for the belemnite material studied here, because only few specimens belong to the subgenus Bln. (Belemnella). For specific assignment within these subgenera, the AV value is of prime importance. A comparison of the standard deviations (S) and 95\% confidence intervals of Belemnella (Pachybelemnella) obtusa Schulz (1979) and of Bln. (P.) sumensis, as recorded by Schulz $(1979$, tables 5, 6) with those of Bln. (Pachybelemnella) samples from the Vijlen Member (Keutgen \& Van der Tuuk, 1991; Keutgen, 1997) has 


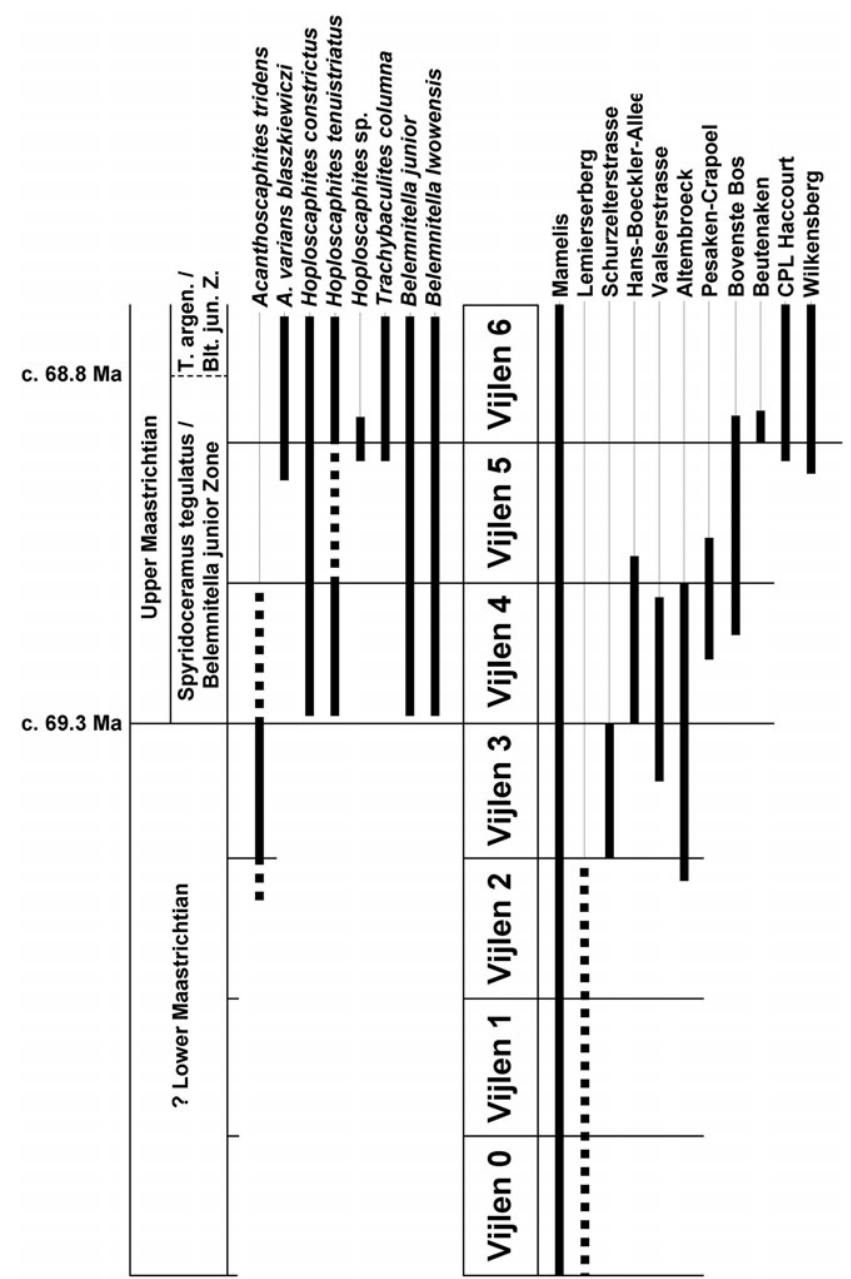

Fig. 4. Time scale for and correlation of Vijlen Member strata with biozones established at Hemmoor, northern Germany. The various localities studied are plotted on the right, and interpretation of strata exposed, as favoured herein, illustrated. In addition, ranges of index cephalopod taxa in the Maastricht-Aachen-Liège area are shown. Dots indicate uncertainty in ranges.

revealed that, firstly, in samples consisting of fewer than c. 20-40 specimens, a conclusion on the homogeneity could not be made using both the $95 \%$ confidence interval and $S$ (Figs 5, 6) and, secondly, that in larger samples with $S>6$, heterogeneity is probable (Fig. 6). Using these criteria, two heterogeneous samples could be identified, i.e. that of Bln. (P.) sumensis from the Bovenste Bos quarry ( $S=7 \%$; see Keutgen \& Van der Tuuk, 1991) and that of the same species from level Bm 2 at Altembroeck ( $S=7.3 \%$; see Keutgen, 1997). The latter sample is of special interest. Although seemingly heterogeneous due to the large variation of $\mathrm{AV}$ and the presence of WQs values spanning the range of both Bln. (P.) obtusa and Bln. (P.) sumensis (Schulz, 1979, fig. 40; Keutgen, 1997, table 2), the means of AV and Lsn indicate the middle Bln. sumensis Zone, a correlation well in line with the occurrence of the probably eastern European species Bln. (Bln.) cf. praearkhangelskii, which invaded western Europe only during a brief interval in the middle Bln. sumensis Zone (Schulz, 1979) and which is limited to level Bm 2 at Altembroeck (Keutgen, 1997). In conclusion, the Belemnella sample of level

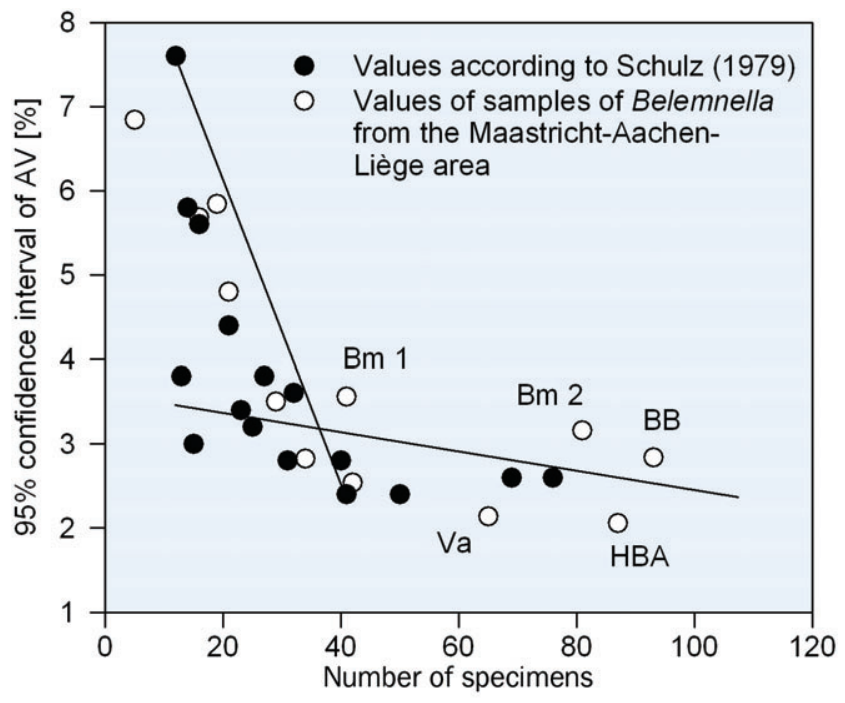

Fig. 5. Scatter plot of the $95 \%$ confidence interval of mean AV values of samples of Belemnella as influenced by sample size; $\bullet=$ samples of Bln. (P.) obtusa and of Bln. (P.) sumensis (see Schulz, 1979, tables 5, 6); $\mathrm{O}=$ samples of the subgenus Bln. (Pachybelemnella) from the Vijlen Member (data from Keutgen \& van der Tuuk, 1991; Keutgen, 1997). Localities and stratigraphic levels are as follows: $B m 1$ and $B m 2=$ belemnite levels $B m 1$ and Bm 2 at Altembroeck section (interval 4); $B B=$ Vijlen Member at Bovenste Bos quarry, with exclusion of burrow fills in the topmost Beutenaken Member (interval 5); $H B A=$ upper glauconitic level of Vijlen Member at temporary Hans-Böckler-Allee I section (top of interval 4); Va = temporary section at Vaalserstraße (intervals 3-4).

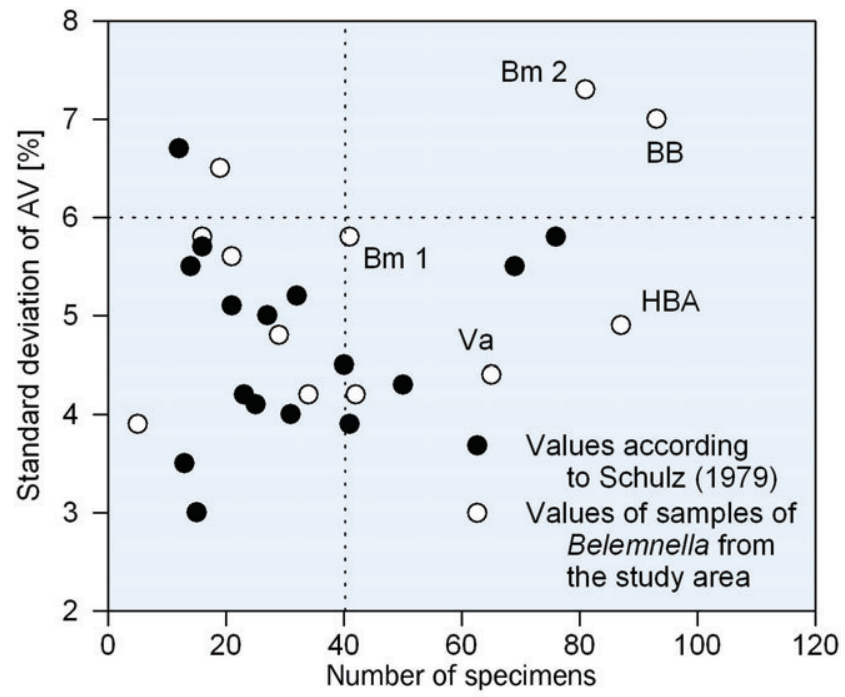

Fig. 6. Scatter plot of standard deviation of mean AV values of samples of Belemnella as influenced by sample size. Samples, localities and stratigraphic levels are as in Fig. 5.

Bm 2 consisted mainly of specimens from a comparatively narrow stratigraphic interval. Assuming that specimens in reworked samples of Belemnella generally are derived mainly from narrow stratigraphic intervals, the means of AV and Lsn, even of a heterogeneous sample, may yield data on the level from which most of the specimens originated (Fig. 7). 


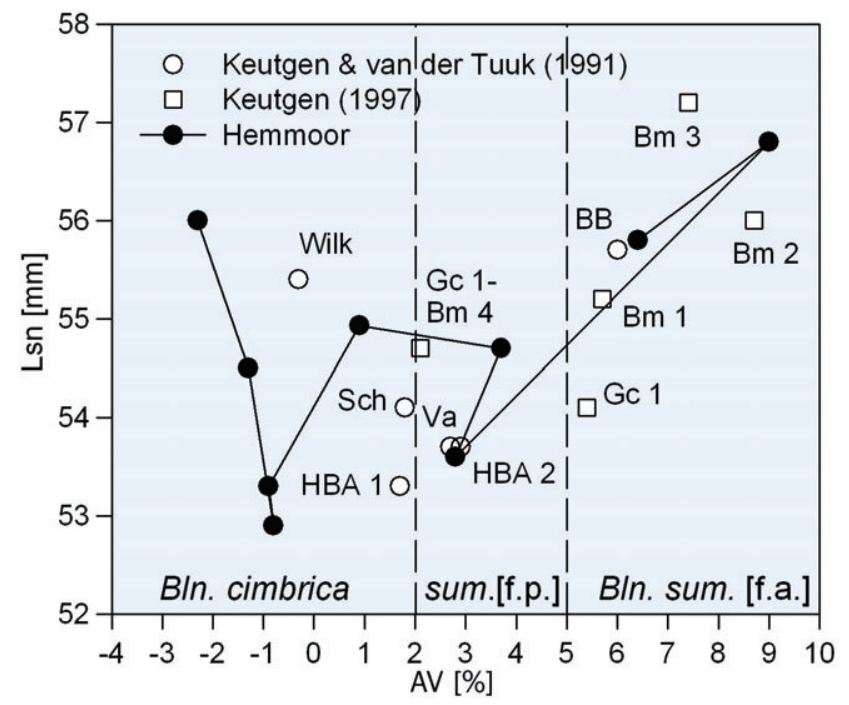

Fig. 7. Comparison of mean AV and Lsn values of samples of the subgenus Bln. (Pachybelemnella) (see Keutgen \& Van der Tuuk, 1991; Keutgen, 1997) with late early Maastrichtian populations of the same subgenus as recorded from Kronsmoor and Hemmoor, northwest Germany (see Schulz, 1979). Samples here considered possibly non-reworked are: Sch $=$ Schurzelterstraße. Samples considered to comprise remanié specimens are: $B m$ 1, Bm 2, Bm 3, GC 1, GC 1-Bm 4 = levels at Altembroeck section, from which belemnites have been analysed; $B B=$ Bovenste Bos quarry; Va = Vaalserstraße; $H B A 1$, $H B A 2$ = Hans-Böckler-Allee I, upper glauconitic layer and level above this layer, respectively; Wilk = Wilkensberg.

Taking into account the range of variation of AV, WQs and Lsn as reported by Schulz (1979) for populations from northern Germany, it is obvious that the range of variation is larger in some samples from the Maastricht-Aachen-Liège area. In the case of a higher variation in a sample it can be concluded that it is heterogeneous as well. Heterogeneity is regarded as a strong argument that a sample contains remanié specimens. The outof-range specimens were identified by comparison with the previous or following populations as described by Schulz (1979), accepting that the stratigraphic interval of a sample of Bln. (Pachybelemnella) should be kept as small as possible. This concept resembles that used by Christensen (1994) for identification of specimens of the genus Gonioteuthis Bayle, 1878 from the Glauconie de Lonzée (Gembloux, province of Namur, Belgium), now the Lonzée Member (Robaszynski et al., 2002). However, it is obvious that this kind of procedure is inaccurate and ignores the facts that with more specimens from a population available, the reported variation could be larger, that reworking itself may have modified single specimens, e.g. their shape, and that belemnite populations from the Maastricht-Aachen-Liège area could have differed slightly in their variation from coeval populations in northwest Germany. This uncertainty is here indicated by using 'cf.' for identification of specimens of Belemnella from a level which contains remanié belemnites.

\section{Localities}

Localities exposing Vijlen Member strata in the MaastrichtAachen-Liège area (Figs 4, 8) are discussed below, with outcrops exposing the oldest intervals (sensu Felder \& Bless, 1994) first. Sections exposed at the localities studied are only briefly described when they have already been discussed at length in previous papers. The belemnite fauna of the outcrops is discussed more extensively.

\section{1 - Mamelis}

The Mamelis sunken road section (locality 62D-79, co-ordinates 312.330/196.450) and the Mamelis borehole section (locality 62D-68), municipality of Vaals (the Netherlands) are complementary without appreciable gap or overlap. Together these sections represent the combined type section of the Vijlen Member (Fig. 3). Felder \& Bless (1994) distinguished seven intervals, in ascending order, Vijlen 0 (thickness $3.2 \mathrm{~m}$ ), Vijlen 1 $(10.5 \mathrm{~m})$, Vijlen $2(10 \mathrm{~m})$, Vijlen 3 (estimated c. $14.3 \mathrm{~m})$, Vijlen $4(8.5 \mathrm{~m})$, Vijlen $5(12 \mathrm{~m})$ and Vijlen 6 (11.5 m). Felder (1997, 2001) was able to identify twelve beds based on foraminiferal frequencies. Reference is made to those papers for detailed descriptions.

Belemnitella junior has been recorded from interval 6 and a reworked specimen of Belemnella ex gr. sumensis/cimbrica from interval 5 (Felder \& Bless, 1994). Here, we add a specimen of Belemnitella lwowensis, which originates either from interval 5 or 6 .

\section{2 - Lemierserberg}

Along the main road (N278) connecting Lemiers and Vaals (the Netherlands), at the corner of the 'Schuurmolenstraat', the base of the Vijlen Member was exposed in a temporary trench, overlying sands of the Vaals Formation. The Vijlen Member here comprised yellowish marls with glauconite and quartz grains, especially in the lowermost portion of the section. Belemnites were not found within the lowermost $0.5 \mathrm{~m}$ exposed, i.e. a belemnite graveyard was not present at that locality. Nevertheless, a few belemnite specimens were collected loose from the interval c. 1-5 m above the base in temporary trenches along the main road. A precise correlation with the Mamelis type section is not yet available. Nevertheless, the relative position of this section to other nearby, well-dated exposures of Vijlen Member deposits implies correlation with a level within intervals 0-2.

Although the sample of Belemnella from Lemierserberg is very small, the mean values of WQs $(2.6 \pm 0.4, \mathrm{~N}=4$, observed range 2.0-2.9) and Lsn (52.6 $\pm 6.2 \mathrm{~mm}, \mathrm{~N}=5)$ clearly indicate that the specimens belong either to Bln. (P.) sumensis or Bln. (P.) cimbrica. The shape of the guard can be used to distinguish these species. The $95 \%$-confidence interval of the mean $\mathrm{AV}$ value 


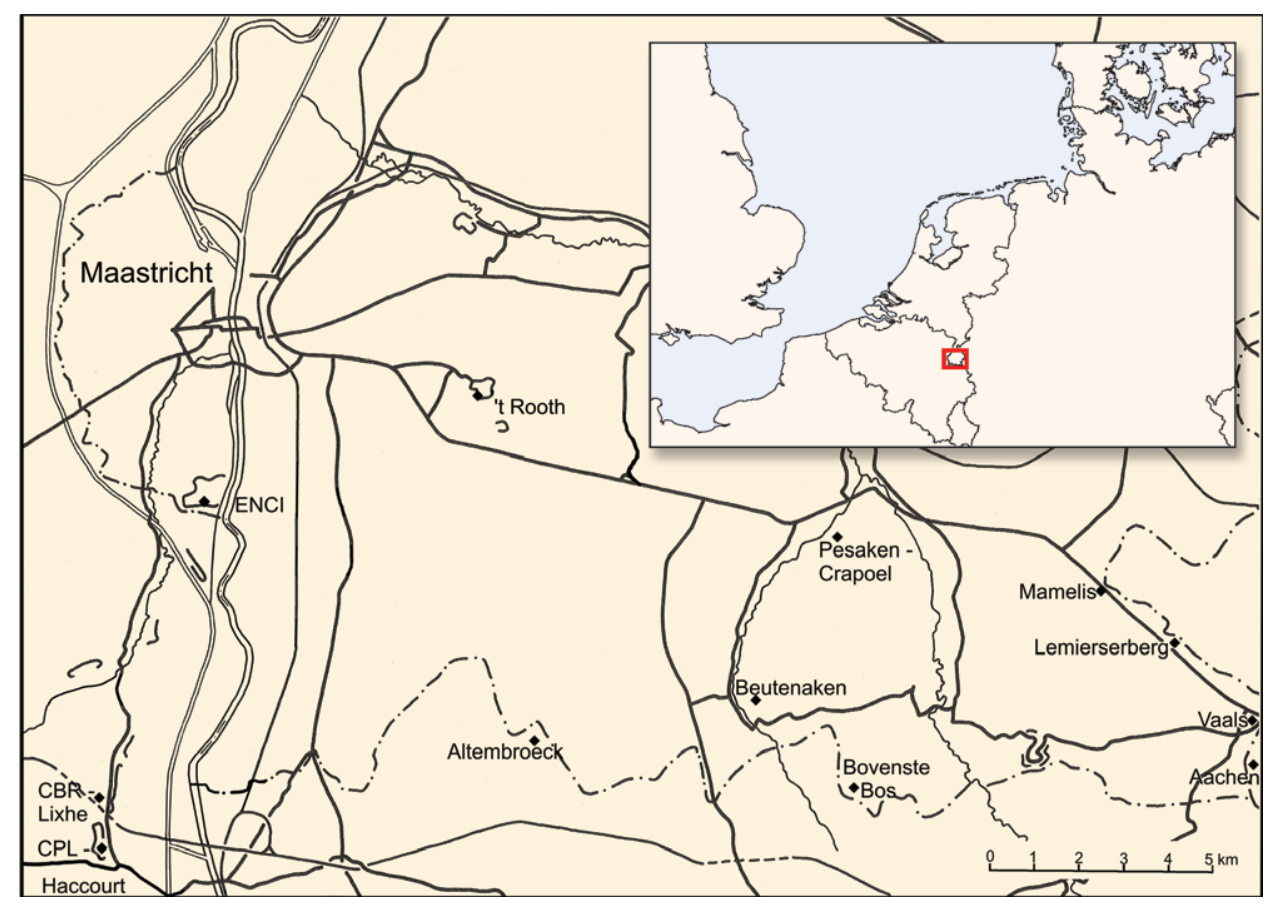

Fig. 8. Map of southern Limburg (the Netherlands), Voerstreek and Liège province (Belgium) and Aachen area (Germany), showing localities referred to in the text. The Aachen city area comprises the localities Schurzelterstraße, Vaalserstraße, Hans-Böckler-Allee and Wilkensberg.
$(4.3 \pm 3.9 \%, N=5)$ of specimens from Lemierserberg ranges from $0.9 \%$ to $7.8 \%$, that of the mean AL value $(-7.5 \pm 2.9 \%, \mathrm{~N}=5)$ from $-10.1 \%$ to $-4.9 \%$, respectively. According to Schulz (1979), populations of Bln. (P.) cimbrica differ from those of Bln. (P.) sumensis in their smaller mean values for $\mathrm{AV}(<2 \%)$ and $\mathrm{AL}$ $(<-10 \%)$. The specimens from Lemierserberg can thus be referred to as Bln. (P.) cf. sumensis. However, the sample is too small to distinguish between early and late forms of that species.

\section{3 - Schurzelterstraße (Aachen)}

The temporary section Schurzelterstraße at Aachen (Germany), as described by Keutgen \& Van der Tuuk (1991), comprised several exposures, accessible between 1978 and 1981 during construction of houses at numbers 460-565, and exposed a yellow-grey, marly limestone. Belemnella collected from this locality are transitional between Bln. (P.) sumensis and Bln. $(P$. cimbrica (Fig. 7), and are here referred to as Bln. ex gr. sumensis/ cimbrica. In addition, Belemnitella sp. could be identified.

The localities Schurzelterstraße and Hans-Böckler-Allee (see below) are situated in close proximity and Keutgen (1996) therefore combined the two localities into a single section. However, the faunal contents of the two localities differ significantly (Keutgen, 1996), which enables correlation of the stratigraphically older deposits formerly exposed at Schurzelterstraße with interval 3 of the Mamelis stratotype section. However, it cannot be ruled out entirely that the base of interval 4 was actually exposed at single exposures listed under the designation 'Schurzelterstraße'. In the light of this, the record from Schurzelterstraße (interval 3) of Belemnitella sp.that resembles Blt. junior (known from intervals 4-6) has to be treated with caution.

\section{4 - Hans-Böckler-Allee (HBA, Aachen)}

This temporary section comprised two closely-spaced construction sites (HBA I = houses at numbers 40-42; HBA II $=$ houses at numbers 50-68) at Aachen (Germany), close to the locality Schurzelterstraße. They were accessible in 1984 and 1991, respectively. Only section HBA I was described and illustrated in Keutgen \& Van der Tuuk (1991, fig. 5). At that locality, $8.4 \mathrm{~m}$ of Vijlen Member were exposed. Within the lowermost $2.4 \mathrm{~m}$, two c. $0.5 \mathrm{~m}$ thick glauconite-rich beds occurred (between c. 0.5-1 $\mathrm{m}$ and 1.9-2.4 $\mathrm{m}$ above the base of the section, respectively). The lower glauconite-rich bed was exposed only briefly in a corner of the temporary section, so belemnites could not be collected. Apart from the glauconite-rich beds, the Vijlen Member exposed at HBA I consisted of a marlstone or marly limestone with a low glauconite content. The upper glauconitic bed marked a distinct colour change in the Vijlen Member deposits, from yellow-grey below to yellow-white above this layer. Locally, changes into a yellowish brown colour appeared in the topmost portion of the section. It may be worth noting that the upper glauconitic layer was locally separated from the underlying yellow-grey marly limestone by a thin (a few millimetres) layer of brownish mud. The origin of the mud is not clear, but it may be due to groundwater percolating down through cracks in the overlying Vijlen Member. The comparatively sharp boundary between the yellow-grey limestone and the glauconitic bed marked by the mud layer attests to a short interruption of sedimentation.

At HBA II, about 10.2 metres of Vijlen Member were exposed. Three glauconite-rich beds were observed, at 0.4-1.4 m, 3.43.9 $\mathrm{m}$ and 7.2-7.5 $\mathrm{m}$ above the base of the section, respectively. Although HBA I and HBA II are closely spaced, it has so far been 
impossible to correlate single glauconite-rich beds with certainty, because neither the thickness of beds nor that of the intercalated marlstones corresponded. This observation is in line with Felder \& Bless (1994) and Felder (1997), who noted that beds within the Vijlen Member cannot be traced over larger distances.

Non-reworked belemnites collected from the upper glauconitic bed at HBA I and also from the interval 0-3 m above the higher glauconite-rich bed belong to Blt. junior and Blt. lwowensis. At HBA II, Blt. junior occurs at least in the upper two glauconite-rich beds, together with numerous remanié specimens assignable to Bln. (Pachybelemnella). With respect to the means of AV and Lsn, remanié specimens of this subgenus from the upper glauconitic bed at HBA I may be compared to populations of Bln. (P.) cf. cimbrica or to Bln. (P.) cf. sumensis, while those from the interval 0-3 $\mathrm{m}$ above the higher glauconiterich bed resemble more those of a late form of Bln. cf. sumensis (means of AV and Lsn; see Fig. 7). Because all of these samples of Bln. (Pachybelemnella) do not differ from those collected at Schurzelterstraße, they are considered transitional between these two species and are here also referred to as Bln. ex gr. sumensis/cimbrica.

Felder \& Bless (1994) analysed a $3 \mathrm{~kg}$ sample from HBA II. The faunal assemblage of foraminifera and ostracods resembled that of interval 4 at the Mamelis stratotype section, which is why the deposits formerly exposed at Hans-Böckler-Allee were correlated with interval 4 of the Vijlen Member. Felder (1997, p. 133) assumed that the Böckler Horizon, marking the top of interval 4, might have been exposed at HBA I, indicating that this section could have extended into interval 5.

\section{5 - Vaalserstraße (Aachen)}

In 1985-1986, about 10 metres of Vijlen Member were exposed during roadworks along the Vaalserstraße, in the vicinity of the Westfriedhof cemetery at Aachen-Melaten (Germany). About $4 \mathrm{~m}$ above the base of the temporary section, a $0.3 \mathrm{~m}$ thick locally indurated, yellowish brown, marly limestone with very high glauconite content and some small quartz grains was exposed. The marly limestone intercalations below this indurated layer also contained glauconite. Up to $3.2 \mathrm{~m}$ above the $0.3 \mathrm{~m}$-thick, locally indurated, marly limestone, the glauconite content remained high and glauconite concentrations occur. In the uppermost $2.5 \mathrm{~m}$ of the section, glauconite content was also high, but not concentrated at certain levels, indicating a trend towards lower contents, especially in the uppermost c. $1 \mathrm{~m}$ of the section exposed (Keutgen \& Van der Tuuk, 1991).

Felder \& Bless (1994) tentatively correlated the upper $6 \mathrm{~m}$ of the Westfriedhof temporary section with interval 2 of the Vijlen stratotype at Mamelis on the evidence of several glauconitic layers containing quartz grains, the frequency of belemnite guards, and the presumed lithostratigraphic position c. $9 \mathrm{~m}$ above the base of the Vijlen Member. However, the relative position of the base of the Vijlen Member at that locality is doubtful at best, because Keutgen \& Van der Tuuk (1991) estimated its position by comparing the Vaalserstraße section with that described by Breddin et al. (1963) from the borehole Vaalserstraße 242-246. Because it has recently been noted that the lithology of the Vijlen Member could change considerably within a limited area (Felder \& Bless, 1994; Felder, 1997), the argumentation of Keutgen \& Van der Tuuk (1991) and also the first and third argument of Felder \& Bless (1994) must be treated with caution. The second argument of Felder \& Bless (1994), in favour of correlation of the Vaalserstraße section with interval 2 of the Vijlen stratotype at Mamelis, the frequency of belemnite guards, has to be considered similarly. The detailed study of the Altembroeck section (Jagt et al., 1995) has shown that levels rich in belemnite guards do not necessarily coincide with belemnite bioclast peaks. The environmental conditions which were needed to fragment belemnite guards were probably different from those involved in the accumulation of rostra. In consequence, the evidence in favour of correlation with interval 2 is weak with respect to the variability of Vijlen Member lithology.

An alternative interpretation of the relative position of the Vijlen Member deposits exposed at the Vaalserstraße locality may be deduced from information given in Breddin et al. (1963, p. 292). At Königshügel, a hill north of the Vaalserstraße, the Vijlen Member reaches a thickness of c. $60 \mathrm{~m}$. About 20-25 m below the top of the member there, at the level of the Bleyberger Straße, glauconitic layers were observed within a light-grey marlstone. Compared with the type locality of the Vijlen Member, the relative position of the glauconitic layers at Bleyberger Straße about 35-40 m above the basis of the Vijlen Member would imply correlation with interval 4. However, the Bleyberger Straße is a nearly horizontal road, which turns into the Vaalserstraße close to the locality mentioned here. Assuming no major fault, this would imply that the transition of intervals 3 to 4 was originally exposed at Vaalserstraße.

A few belemnites were collected up to $1 \mathrm{~m}$ below the locally indurated limestone, but most are derived from the interval immediately below to up to c. $1.5 \mathrm{~m}$ above this layer. A smaller number of specimens were collected from the upper c. $2 \mathrm{~m}$ of the section exposed. Specimens of Belemnella from the Vaalserstraße do not differ from those collected at Schurzelterstraße and Hans-Böckler-Allee. They are thus considered intermediate between Bln. (P.) sumensis and Bln. (P.) cimbrica; however, with respect to their mean $\mathrm{AV}$ and Lsn values, they are more typical of a late form of Bln. (P.) sumensis (Fig. 7). They are best referred to as Bln. ex gr. sumensis/cimbrica. Representatives of Belemnitella collected at Vaalserstraße are here referred to Belemnitella sp. (1 specimen) and Belemnitella cf. lwowensis (1 specimen). The latter specimen from the middle portion of the section would imply a correlation with interval 4 or younger deposits of the Vijlen Member. 
Because neither bioclasts nor foraminiferal samples are available from the Vaalserstraße section, its position within the Vijlen Member must be estimated based on macrofaunal contents. The record of a well-preserved specimen of Acanthoscaphites (A.) tridens (see Jagt et al., 1999) collected in the lower portion of the section exposed (H. Knoll, letter of 17 April 2007) and the presence of large specimens of the holasteroid echinoid Cardiaster granulosus (Goldfuss, 1829) immediately below the indurated layer favour correlation of the lowermost 4 metres with interval 3, and possibly even older deposits. Index species such as Diplodetus duponti or Hoploscaphites constrictus have not been identified from levels above the indurated layer, but the record of Blt. cf. lwowensis from the Vaalserstraße section suggests the presence of interval 4 or even younger deposits of the Vijlen Member. In this context, the record of the isocrinid crinoids 'Isocrinus' lanceolatus (Roemer, 1840)? and Nielsenicrinus agassizii (Von Hagenow, 1840) from this locality (interval 4) may be of interest as well (Jagt, 1999b), because in the MaastrichtAachen-Liège area these species are known exclusively from the upper portion of the Vijlen Member, i.e. from interval 4 or younger (e.g., at Mamelis, Altembroeck and Hans-Böckler-Allee). In summary, preliminary macrofossil evidence would suggest that the boundary level between intervals 3 and 4 of the Vijlen Member was exposed at Vaalserstraße, perhaps close to the base or top of the locally indurated, yellowish brown, glauconitic limestone c. $4 \mathrm{~m}$ above the base of the section.

\section{6 - Altembroeck}

The Altembroeck section (Voer, northeast Belgium) was described in detail by Jagt et al. (1995) and Felder (2001), including a stratigraphical interpretation based on bioclasts. The belemnitebearing portion of the section (interval 4) was also discussed by Keutgen (1997). At Altembroeck, the first typically late Maastrichtian Blt. junior and Blt. lwowensis were collected from level Bm 1, about $1.2 \mathrm{~m}$ above the base of interval 4 (Felder, 2001, fig. 40). From layers below Bm1, no belemnites were available.

Keutgen (1997) described species of Belemnella from levels $\mathrm{Bm} \mathrm{1,} \mathrm{Bm} \mathrm{2,} \mathrm{Bm} \mathrm{3,} \mathrm{Gc} \mathrm{1,} \mathrm{the} \mathrm{interval} \mathrm{between} \mathrm{Gc} 1$ and Bm 4, as well as from level $\mathrm{Bm}$, all of which are here considered to have been reworked. The records have now been reinterpreted based on the means of AV and Lsn (Fig. 7) and the range of variation documented in Keutgen (1997, table 2), yielding the following picture:

- Bm 1: the means of AV and Lsn indicate the presence of early forms of Bln. (P.) cf. sumensis (Fig. 7), but the observed range of variation of $\mathrm{AV}$ is larger than that documented for Bln. (P.) sumensis (f.a.) by Schulz (1979). AV values of up to 25\% support the presence of Bln. (P.) cf. obtusa Schulz, 1979 within this sample.

- Bm 2: as mentioned above, the means of AV and Lsn of Bln. (Pachybelemnella) specimens (Fig. 7), in addition to the presence of Bln. (Bln.) cf. praearkhangelskii allow the conclusion to be drawn that most of the specimens found at level Bm 2 were reworked from deposits that were first laid down during the middle Bln. sumensis Zone (sensu germanico). However, as at level Bm 1, the range of the AV value is larger than that recorded by Schulz (1979). It includes values typical of $B l n$. (P.) cf. obtusa and also of late forms of Bln. (P.) cf. sumensis. Keutgen (1997) reported a WQs value as low as 1.1 which, according to Schulz (1979, fig. 40), may be considered typical of Bln. (P.) obtusa.

- Bm 3: the means of AV and Lsn indicate a middle Bln. sumensis Zone provenance for the Bln. (Pachybelemnella) specimens, albeit Bln. cf. praearkhangelskii could not be identified at level Bm 3. This assignment corresponds to the documented range of variation.

- Gc 1: in the case of the Bln. (Pachybelemnella) specimens collected from this level, a comparison of the means of AV and Lsn with those of populations from northwest Germany proved unsuccessful (Fig. 7). Most specimens may be referred to $B l n$. (P.) cf. sumensis. The sample may contain both early and late forms of that species.

- Interval Gc 1 to Bm 4, Bm4: specimens in these samples are here lumped together. The means of both are virtually identical and plot close to those of populations of either Bln. (P.) sumensis 'Schichtgruppenfauna' SGF 47-54 m or Bln. (P.) cimbrica SGF 54-60 $\mathrm{m}$ at Hemmoor (Fig. 7). The documented range of variation also indicates the presence of early forms of Bln. (P.) cf. sumensis.

In summary, the occurrence of remanie belemnites of the early Maastrichtian Bln. obtusa, sumensis and cimbrica zones in interval 4 at Altembroeck is probable, with most of specimens having originated from the Bln. sumensis Zone.

\section{7 - Pesaken-Crapoel}

At the Pesaken-Crapoel road section, near Gulpen (the Netherlands), a few metres of white marl belonging to the Zeven Wegen Member are overlain by about 5 metres of almost exclusively greensand in its lower portion and a gradually increasing marl content towards its top (Hofker, 1966, figs 16, 17). The boundary between the Zeven Wegen Member and the glauconitic greensand is distinct. According to Hofker (1966), the lowermost c. $3.5 \mathrm{~m}$ of the glauconitic layer yielded species typical of his foraminiferal zone B. On this evidence, this portion of the layer was referred to the Beutenaken Member in some papers (Keutgen, 1996; Keutgen \& Jagt, 1999). The upper c. $1.5 \mathrm{~m}$ of the glauconitic layer, which is characterised by a relatively higher marl content, has yielded foraminifera of Zone $C$ and was considered to represent the Vijlen Member. The transition from the greensand to the overlying coarse-grained, glauconite-rich marl is more or less gradual. Hofker (1966) observed belemnite-enriched horizons within the glauconitic layer, for example one about $3.5 \mathrm{~m}$ above its base. 
With respect to the belemnites collected, the glauconitic layer at Pesaken-Crapoel may be subdivided into three parts. The lower c. $2 \mathrm{~m}$ have yielded a belemnite fauna consisting of frequent Belemnitella cf. minor II Christensen, 1995 with a mean Birkelund Index of about 3.8. Were it not for a single specimen of Blt. junior, collected about 1.3-1.4 $\mathrm{m}$ above the base of the glauconitic layer, this fauna could have been regarded as typical of the upper upper Campanian, with respect to the Campanian/ Maastrichtian boundary definition at Tercis les Bains (Landes, southwest France), ratified as the Global Standard Stratotype Section and Point (GSSP) for that boundary (Odin \& Lamaurelle, 2001).

From the interval c. 2.0-3.5 $\mathrm{m}$ above the base of the glauconitic layer, Blt. cf. minor II with a mean Birkelund Index of about 3.6 has been collected. A non-reworked Blt. junior was found about 2.2-2.4 $\mathrm{m}$ above the base of the glauconitic layer and a single specimen (NHMM 2007 006) of Bln. (P.) cf. inflata (Arkhangelsky, 1912) (Fig. 11I-K) comes from c. 3.2-3.4 m above the base of the glauconitic layer, plus two additional specimens (NHMM 2007 005, NHMM 2007 007) whose exact provenance is unknown. Their critical characters are given in Table 1 . The ratio Qp/Dp of these specimens is typical of the upper Bln. pseudobtusa Zone (Schulz, 1979, fig. 51).

Table 1. Measurements of critical characters of Belemnella (Pachybelemnella) cf. inflata (Arkhangelsky, 1912) (NHMM 2007005 2007 007) from the basal Vijlen Member near Pesaken-Crapoel.

\begin{tabular}{llll}
\hline Character & NHMM 2007 006 & NHMM 2007 005 & NHMM 2007 007 \\
\hline Ls (mm) & 57.5 & 58.0 & estimated 60 \\
Dp (mm) & 6.7 & 9.3 & 9.0 \\
Qp & 0.96 & 0.98 & 0.96 \\
Lsn (mm) & 69.8 & 65.5 & c. 68 \\
AV (\%) & 27.6 & 30.7 & c. 23 \\
AL (\%) & 6.0 & 12.7 & c. 15 \\
\hline
\end{tabular}

The interval c. $3.5-5 \mathrm{~m}$ above the base of the glauconitic layer has yielded several Bln. (P.) cf. obtusa (f.m.) (mean values: WQs: $1.6 \pm 0.4, \mathrm{~N}=9$; Lsn: $49.9 \pm 3.8 \mathrm{~mm}, \mathrm{~N}=15 ; \mathrm{AV}: 7.4 \pm 4.9 \%$, $\mathrm{N}=14$ ) and a single specimen each of Blt. cf. minor II and Blt. lwowensis.

In the Crapoel 62C-74 borehole, close to the road section, the c. $5 \mathrm{~m}$ thick glauconitic layer is also present. Felder (1997, fig. 5) proposed correlation of this layer with the upper portion of interval 4 and the lowermost portion of interval 5. Later, Felder (2001, fig. 14) provided a more detailed analysis of the bioclasts; however, this seemed to indicate ecozone IIb, which is typical of the Beutenaken Member. This identification of ecozone IIb in the glauconitic layer is probably due to the fact that the layer consisted mainly of reworked material from the upper Campanian Beutenaken Member (with respect to the Campanian/Maastrichtian boundary as defined at Tercis les
Bains; see Odin \& Lamaurelle, 2001) that was redeposited during the late Maastrichtian. The belemnite fauna of the road section favours this interpretation. In the present paper, the glauconitic layer in the borehole Crapoel 62C-74 is correlated with the upper portion of interval 4 and the basal part of interval 5 of the Vijlen type section at Mamelis (Fig. 4), in line with Felder (1997).

\section{8 - Bovenste Bos quarry}

The Bovenste Bos quarry (locality 62D-27) is a small, disused and now largely overgrown quarry on the southern slope of the River Geul valley at Epen, the Netherlands. It was described in detail by, among others, Hofker (1966), Robaszynski et al. (1985), Keutgen \& Van der Tuuk (1991), Felder \& Bless (1994) and Felder (2001), the last-named paper including a stratigraphical interpretation based on bioclasts. At this quarry, the Vijlen Member starts with a glauconitic greensand-type of sediment that fills burrows piping down into the topmost Beutenaken Member and containing a multitude of belemnite guards ('belemnite graveyard'). The Bovenste Bos quarry is the type locality of the Bovenste Bos Horizon, which, by definition, represents the contact between the Beutenaken and Vijlen members. Subsequently, the interpretation of this horizon has been extended so as to characterise the base of the Vijlen Member at any locality where this member is exposed. It is worth noting here that the stratotypes of the Bovenste Bos Horizon and the Vijlen Member have been defined at different localities.

The Vijlen Member overlying the Beutenaken Member is characterised by an up to $5 \mathrm{~cm}$ thick 'conglomerate', which consists of belemnite guards and fragments, a few rounded quartz grains and quartzite pebbles. These components are embedded in a glauconitic, yellowish grey marlstone that differs from the material in the burrows. The boundary between the burrow infill and the yellowish grey marlstone is distinct and attests to a discontinuity surface (Jagt, 1999a).

The thin 'conglomerate' is overlain by $0.8-1 \mathrm{~m}$ of yellowish grey clayey and calcareous marlstones with a relatively high glauconite content. According to Felder \& Bless (1994), this portion of the Vijlen Member consists of several glauconitic layers with glauconite-filled burrows and/or depressions. In this portion of the section, one of us (NK) has also observed a few partially indurated boulders of yellowish-grey, glauconitic and phosphatic marl, which otherwise do not differ from the surrounding softer marlstones. They might represent relicts of broken-down incipient hardground layers. In addition, phosphatic fossils (the heteromorph ammonite Baculites sp., bivalves and gastropods) have been collected from this level. The Vijlen Member above the basal c. $1 \mathrm{~m}$ contains less glauconite. Felder (2001, fig. 38) interpreted the lowermost c. $0.8 \mathrm{~m}$ of the Vijlen Member at the Bovenste Bos quarry as relicts of intervals $0-5$ and referred the overlying portion to interval 6 of the Mamelis type section. 
For the present study, belemnites occurring within the burrows of the topmost Beutenaken Member have been restudied in more detail. First of all, two groups of specimens could be distinguished: small, well-preserved ones (nine specimens of the subgenus Bln. (Pachybelemnella)) and larger ones showing clear signs of erosion. In a few of the specimens of the first group even the fragile anterior part of the alveolus has been preserved. Moreover, the colour of these guards is more honey-like and less grey or green-red than that of the other specimens. The Belemnella specimens of this small group could not be identified with certainty, because their small size did not allow splitting of the guards and measurement of WQs values. With respect to their means and range of variation (Lsn: $51.2 \pm 2.9 \mathrm{~mm}, \mathrm{~N}=9$, observed range 46.8-54.8 mm; AV: $9.5 \pm 7.4 \%, N=9$, observed range $-3.7-20.9 \%$ ), they resemble typical or late forms of Bln. (P.) obtusa or Bln. (P.) sumensis. Thus, these specimens are here referred to as Bln. ex gr. obtusa/sumensis.

The second group of specimens, which comprises both Bln. (P.) cf. obtusa and Blt. cf. minor II, shows clear signs of reworking. Analysis of this group has revealed that about 37\% of specimens were complete or near-complete (specimens were considered complete when the AV value could be calculated). This percentage was larger for specimens originating from the interval 0-0.65 $\mathrm{m}$ than for those collected from 0.65-1 m below the top of the chalkstone (Table 2). About 33\% of the Belemnella specimens were complete, compared to $53 \%$ of the Belemnitella. This distinct difference can be attributed to the more robust structure of the guard in Blt. cf. minor II, especially the rostrum cavum. Whereas the percentages of complete rostra of $B l n$. (P.) cf. obtusa in the upper $(0-0.65 \mathrm{~m})$ and lower part (0.65-1.00 m) of the burrows were similar, the corresponding percentages of Blt. cf. minor II differed considerably (Table 2). From the upper interval $(0-0.65 \mathrm{~m})$ four complete specimens were collected, whereas the lower part of the burrows (0.65-1 m) yielded only $36 \%$ near-complete specimens. Although this relationship might be biased, because indeterminate rostrum solidum fragments of Belemnitella might have been overlooked, the large number of fragments of Blt. cf. minor II in the lower section of the burrows is remarkable. Moreover, the percentage of Blt. cf. minor II in the belemnite fauna is twice as high in the lower part of the burrows (17\%) than in the upper portion $(8 \%)$. These results are best interpreted by assuming that in the Bovenste Bos quarry some of the specimens referred to Blt. cf. minor II were washed down the burrows prior to the bulk of sediment with Bln. (P.) cf. obtusa.

With respect to their mean values (WQs: $1.8, \mathrm{~N}=2$; Lsn: $57.4 \pm 5.8 \mathrm{~mm}, \mathrm{~N}=48 ; \mathrm{AV}: 16.1 \pm 7.1 \%, \mathrm{~N}=32$ ), the less well-preserved specimens of Bln. (Pachybelemnella) from the 'belemnite graveyard' resemble Bln. (P.) obtusa (f.a.) at Kronsmoor. A single specimen ( $\mathrm{Lsn}=68 \mathrm{~mm}, \mathrm{AV}=28 \%$ ) plots well within the range of Bln. (P.) inflata, but could also be considered an extreme variant of Bln. (P.) obtusa. Schulz (1979) distinguished two 'Schichtgruppenfaunen' in the lower Bln. obtusa Zone at Kronsmoor. The older one (SGF 15-18 m) contained several specimens with AV values $>20 \%$, the younger one (SGF 18-21 m) shorter specimens (Lsn $<50 \mathrm{~mm}$ ). Within the 'belemnite graveyard' at the Bovenste Bos quarry both 'extreme' forms are present in the lower $(0.65-1.00 \mathrm{~m})$ as well as in the upper portion (0.00-0.65 m) of the burrows. This may be interpreted as a sign of heterogeneity of the belemnite sample. Last, but not least, Bln. (Bln.) cf. lanceolata has been identified in the 'belemnite graveyard' of the Bovenste Bos quarry (Keutgen \& Van der Tuuk, 1991), in addition to two specimens of Belemnitella, which according to Christensen (1995, p. 72) are out of the range of Blt. cf. minor II ('Belemnitella ex gr. mucronata' in Keutgen \& Van der Tuuk, 1991). Both specimens of Belemnitella are here referred to Blt. junior, albeit with a query, probably indicating a late Maastrichtian age in terms of belemnite stratigraphy of the greensand that filled the burrows within the topmost Beutenaken Member.

In summary, belemnites were washed down the burrows penetrating the topmost Beutenaken Member during more than a single event and derived from different stratigraphical levels. The first set of belemnites that entered the burrows consisted mainly of Blt. cf. minor II, probably derived from Beutenaken Member deposits. Later, the burrows were filled mainly with Bln. (P.) cf. obtusa originating from different stratigraphical levels within the Bln. obtusa Zone. Bln. (P.) cf. sumensis is probably also present in the burrows.

The belemnite sequence within the burrows, Blt. cf. minor II below and Bln. (P.) cf. obtusa above, is reminiscent of the

Table 2. Distribution and frequency of belemnites with clear signs of erosion found in burrows within the chalkstone underlying the Vijlen Member at the Bovenste Bos quarry. Belemnites from intervals 0-0.65 m and 0.65-1 m below the top of the chalkstone were analysed separately (Blt. = Belemnitella; Bln. = Belemnella).

\begin{tabular}{|c|c|c|c|c|c|c|c|c|c|}
\hline & $\begin{array}{l}\text { All } \\
\text { specimens }\end{array}$ & $\begin{array}{l}\text { Specimens } \\
\text { from } \\
0-0.65 \mathrm{~m}\end{array}$ & $\begin{array}{l}\text { Specimens } \\
\text { from } \\
0.65-1 \mathrm{~m}\end{array}$ & $\begin{array}{l}\text { Bln. cf. obtusa } \\
\text { all specimens }\end{array}$ & $\begin{array}{l}\text { Bln. cf. obtusa } \\
\text { from } 0-0.65 \mathrm{~m}\end{array}$ & $\begin{array}{l}\text { Bln. cf. obtusa } \\
\text { from } 0.65-1 \mathrm{~m}\end{array}$ & $\begin{array}{l}\text { Blt. cf. minor } \\
\text { II all } \\
\text { specimens }\end{array}$ & $\begin{array}{l}\text { Blt. cf. minor } \\
\text { II from } \\
0-0.65 \mathrm{~m}\end{array}$ & $\begin{array}{l}\text { Blt. cf. minor } \\
\text { II from } \\
0.65-1 \mathrm{~m}\end{array}$ \\
\hline Number & 112 & 48 & 64 & 94 & 41 & 53 & 15 & 4 & 11 \\
\hline$\%$ of fauna & & & & 83.9 & 85.4 & 82.8 & 13.4 & 8.3 & 17.2 \\
\hline \multicolumn{10}{|c|}{$\%$ of complete } \\
\hline specimens & 36.6 & 41.7 & 32.8 & 33.0 & 34.1 & 32.1 & 53.3 & 100 & 36.4 \\
\hline
\end{tabular}


sequence within the $5 \mathrm{~m}$ thick glauconitic layer in the PesakenCrapoel road section, as is the glauconitic greensand-type of sediment. Because Blt. junior occurs in the glauconitic greensand at both localities, the glauconitic levels may be correlated. Consequently, at the Bovenste Bos quarry, deposition of Vijlen Member strata (greensand) started in the burrows of the topmost Beutenaken Member during the deposition of interval 4 or 5, i.e. during the Blt. junior Zone. The lower c. $0.8 \mathrm{~m}$ of the marlstone may be regarded as a condensed deposit, followed by interval 6 (Fig. 4).

The marlstones of the Vijlen Member at the Bovenste Bos quarry (interval 5-6) have yielded the typically late Maastrichtian Blt. junior and Blt. lwowensis. The means of AV and Lsn of remanié specimens of $B l n$. (Pachybelemnella) indicate the presence of early forms of Bln. (P.) cf. sumensis (Fig. 7), but the observed range of variation of $\mathrm{AV}$ is larger than that documented for Bln. (P.) sumensis (f.a.) by Schulz (1979). AV values of up to $29.3 \%$ and WQs values as low as 1.5 support the presence of $B \ln .(P$.$) cf. obtusa, while AV values as small as$ $-6.4 \%$ that of late forms of Bln. (P.) cf. sumensis, and possibly also of Bln. (P.) cf. cimbrica.

\section{9 - Beutenaken}

The Habets quarry at Beutenaken (the Netherlands, locality 62C-22) is the stratotype of the Beutenaken Chalk Member and its succession is basically similar to that at Bovenste Bos quarry. From this quarry Keutgen \& Van der Tuuk (1991) described a few belemnites, all collected loose and assumed to have come from the lowermost part of the Vijlen Member, at that locality considered to correspond to interval 6 (Felder, 2001, fig. 13). A re-investigation of the belemnite material from the Habets quarry has now revealed its heterogeneous character. Whereas the majority of specimens of Bln. (Pachybelemnella) resemble Bln. (P.) cf. obtusa (f.m.) on the means of WQs (1.4, $\mathrm{N}=2)$, Lsn (53.3 mm, $\mathrm{N}=11)$ and $\operatorname{AV}(11.8 \%, \mathrm{~N}=8)$, a single specimen must be attributed either to $B \ln$. ( $P$.) cf. obtusa (f.a.) or to $B \ln$. $(B \ln$.) cf. inflata, due to its primitive shape (Lsn = $60.9 \mathrm{~mm} ; \mathrm{AV}=29.8 \%$ ). A fragment probably belonging to Blt. cf. minor II was also found.

Hofker (1966, fig. 14) mentioned a second locality near Beutenaken, the 'Road west of Beutenaken' on the opposite side of the River Gulp valley. From a nearby field, numerous belemnite guards were collected, which are assumed to stem from the lowermost Vijlen Member (interval 6). This fauna was also studied by Keutgen \& Van der Tuuk (1991). It is basically identical to that from the Habets quarry, but single specimens each of Belemnella (Belemnella) cf. lanceolata (Von Schlotheim, 1813) and of Blt. junior or Blt. lwowensis were also identified. of this latter comparatively large, strongly vascularised and pseudogranulate specimen (M.J. van Birgelen Collection), only a small part of the alveolus is preserved, so that the AV value could not be calculated. Its Birkelund Index was reported to be
5.4 (Keutgen \& Van der Tuuk, 1991; specimen mentioned under 'Belemnitella ex gr. mucronata'). The presence of this specimen indicates the Blt. junior Zone for the lowermost Vijlen Member near Beutenaken.

\section{0 - The former Ciments Portland Liégeois (CPL) quarry, Haccourt}

This quarry (locality $62 \mathrm{H}-9$ ) is situated on the left bank of the River Maas, about $10 \mathrm{~km}$ south of Maastricht, in the Belgian province of Liège. The deposits exposed here have been described in several papers, e.g. Robaszynski et al. (1985), to which reference is made. Bioclast stratigraphy (Felder, 1997, 2001) correlated the Vijlen Member exposed here with the upper portion of interval 5 and interval 6 . Belemnites described from these levels belong to the typically late Maastrichtian Blt. junior and Blt. lwowensis (Keutgen \& Van der Tuuk, 1991; Christensen et al., 2004). Representatives of Bln. (P.) ex gr. sumensis/cimbrica are restricted to burrow fills in the chalkstone underlying the Froidment Horizon at the base of the Vijlen Member.

\section{1 - Wilkensberg (Aachen)}

At Wilkensberg (or 'Willkommsberg' in older literature) near the Computer Museum of RWTH Aachen (Melatener Straße, Aachen, Germany), up to $15 \mathrm{~m}$ of Vijlen Member and the lowermost portion of the Lixhe (0rsbach) Member were exposed between 1983 and 1991. From the nearby locality Melaten, Ebensberger (1962) mentioned Bolivinoides gr. draco resembling B. draco draco (Marsson, 1878), which is why the deposits exposed at Wilkensberg are correlated with interval 6 . Because this unit is characterised by a thickness of $11.5 \mathrm{~m}$ at the stratotype section near Mamelis, it is probable that the top of interval 5 was also exposed for a short period near Wilkensberg in 1991. However, most of the fossils collected at the latter locality derived from interval 6. Interval 6 at Wilkensberg yielded common Blt. junior and rare Blt. lwowensis. Specimens of Belemnella may be referred to Bln. ex gr. sumensis/cimbrica, although the means of $\mathrm{AV}$ and $\mathrm{AL}$ of the sample are more typical of $B \ln$. (P.) cimbrica (see Keutgen \& Van der Tuuk, 1991).

\section{Discussion}

\section{General results}

Most of the Vijlen Member sections studied in the MaastrichtAachen-Liège area have yielded specimens of Belemnitella which resemble the late Maastrichtian Blt. junior or Blt. lwowensis. These specimens frequently co-occur with typically early Maastrichian species of Belemnella such as Bln. (P.) cf. obtusa, $B l n$. (P.) cf. sumensis, Bln. (Bln.) cf. praearkhangelskii and Bln. $(P$.$) cf. cimbrica. At Pesaken-Crapoel, they are also associated$ with latest Campanian taxa (with respect to the Campanian/ 
Maastrichtian boundary definition at Tercis les Bains), such as Bln. (P.) cf. inflata and Blt. cf. minor II. The frequency of late Maastrichtian representatives of Belemnitella at some of the localities studied is surprisingly low (Table 3). For example, at the Bovenste Bos quarry or at the Pesaken-Crapoel road section, species of Belemnitella typical of the Blt. junior Zone account for less than $5 \%$ of the belemnite assemblages.

Table 3. Approximate percentages of non-reworked Belemnitella within the late Maastrichtian belemnite samples from the Maastricht-AachenLiège area, in part after data supplied by Keutgen \& van der Tuuk (1991); No. bel. = number of belemnites; $n r=$ non-reworked; Blt. = Belemnitella; Bln. = Belemnella; $A$. = Allee.

\begin{tabular}{llllll}
\hline Locality & Units & \multicolumn{2}{l}{ No. } & No. nr \% nr Remarks \\
& & bel. & Blt. & Blt. & \\
\hline Pesaken-Crapoel & Vijlen 4 & 84 & 3 & 3.6 & reworked Bln. and Blt. \\
Altembroeck & Vijlen 4 & 289 & 23 & 8.0 & reworked Bln. and Blt. \\
Hans-Böckler-A. & Vijlen 4 & 100 & 10 & 10.0 & reworked Bln. \\
Bovenste Bos & Vijlen 4-5 & 268 & 9 & 3.4 & reworked Bln. and Blt. \\
CPL-Haccourt & Vijlen 5-6 & 21 & 21 & 100 & \\
Wilkensberg & Vijlen 6 & 48 & 20 & 41.7 & reworked Bln. \\
\hline
\end{tabular}

Based on the co-occurrence of Blt. junior and late early Maastrichtian species of Belemnella, Keutgen (1996) erroneously noted that Blt. junior first appeared in the Maastricht-AachenLiège area as early as in the late early Maastrichtian Bln. sumensis Zone. However, a re-evaluation of his material with respect to the recently established bioclast zonation of the Vijlen Member revealed that at least the sections exposing intervals 4-6 of this member contain identical populations of Belemnitella (Blt. junior and Blt. lwowensis), but different species of Belemnella. It is here concluded that these deposits are of late Maastrichtian age and that the early Maastrichtian and latest Campanian belemnite index taxa collected at these levels must be considered reworked. Due to the comparatively good preservation also of remanié material of Belemnella, Keutgen $(1996,1997)$ and, earlier Keutgen \& Van der Tuuk (1991), were unable to distinguish between remanié and nonreworked samples of Belemnella, which resulted in the record of typical Blt. junior in the so-called 'early Maastrichtian'. Moreover, Keutgen \& Van der Tuuk (1991) misinterpreted the concept of Belemnitella pulchra Schulz, 1982 and included the late Maastrichtian Blt. lwowensis in their 'Blt. pulchra'.

Remanié belemnite rostra are frequently accumulated at certain levels within the Vijlen Member. Doyle \& Macdonald (1993) proposed a model for the development of belemnite accumulations, which involved five possible pathways: postspawning mortality, catastrophic mass mortality, predation concentration, stratigraphical condensation and resedimentation. To separate these pathways, palaeontological and sedimentological criteria have been introduced. According to scenarios presented by those authors (p. 78), the belemnite accumulations at the base of the Vijlen Member in the region between Beutenaken, Pesaken-Crapoel, and Bovenste Bos, which represent intervals 4-6 of the Vijlen Member, reflect concentration by condensation, as this member is incompletely developed in this area. Belemnite rostra at these localities are eroded and associated with obvious omission surfaces. For the Altembroeck section (Vijlen Member interval 4), Keutgen (1997) proposed reworking of belemnite rostra from older layers and transport by currents. These belemnite accumulations may be interpreted as kinds of stratigraphical condensates (sensu Doyle \& Macdonald, 1993). For the Vijlen Member, stratigraphic condensation represents the most probable origin for the belemnite accumulations, but resedimentation processes, e.g. of older belemnite accumulations, contributed to the accumulations as well. However, reworked rostra of Belemnella in this member are not limited to belemnite accumulations. The frequency of remanié belemnite rostra in the Vijlen Member can at least partly be explained by the deposition of a significant portion of this member in channel-like structures, which facilitated reworking of belemnites from older deposits, originally present at the channel margins, and their preservation within the channel deposits.

\section{Intervals 4-6 of the Vijlen Member}

The upper portion of the Vijlen Member (intervals 4-6) is well exposed, while its lower portion (intervals $0-3$ ) is less accessible. Intervals 0-2 are known mainly from boreholes. Because more information on belemnites from intervals 4-6 is available, this portion of the Vijlen Member is discussed separately.

In the Vijlen Member of the Maastricht-Aachen-Liège area, the oldest unequivocal records of Blt. junior and Blt. lwowensis stem from interval 4, and material was collected at several localities. The base of the Blt. junior belemnite Zone is generally considered to correspond to the base of the upper Maastrichtian in terms of belemnite stratigraphy (Christensen, 1996). This interpretation is followed herein. The best exposed and most thoroughly studied section to date is that at Altembroeck, where intervals 2-4 were investigated (Jagt et al., 1995; Felder, 2001). In this section, the first representatives of both species have been collected from level Bm 1, about $1.2 \mathrm{~m}$ above the base of interval 4 .

Although representatives of Belemnitella are comparatively rare within intervals 4-6 of the Vijlen Member, the tendency of Blt. lwowensis to constitute a smaller portion of the belemnitellid fauna towards the top of the Vijlen Member is clear. In strata referred to interval 4 and possibly the lower portion of interval 5 , this species usually is as common as Blt. junior. In deposits referred to the upper portion of interval 5 and to interval 6 , the percentage of Blt. lwowensis in the belemnitellid fauna is reduced to about $10 \%$ (Table 4). In comparison, Christensen et al. (2004) also noted that Blt. lwowensis constituted about $9 \%$ of the late Maastrichtian belemnitellid fauna in the Maastricht area (the Netherlands, Belgium). 
Table 4. Approximate percentages of Belemnitella lwowensis Naidin, 1952 in the late Maastrichtian belemnitellid fauna of the Vijlen Member, in part after data supplied by Keutgen \& Van der Tuuk (1991); No. Blt. jun. = number of specimens of Belemnitella junior Nowak, 1913; No. Blt. Iw. = number of specimens of Blt. Iwowensis; \% Blt. Iw. = percentage of Blt. lwowensis; $H B A=$ Hans-Böckler-Allee.

\begin{tabular}{llccc}
\hline Locality & Units & No. Blt. jun. & No. Blt lw. & \% Blt. lw. \\
\hline Pesaken-Crapoel & Vijlen 4 & 3 & 1 & 25 \\
Altembroeck & Vijlen 4 & 11 & 12 & 52 \\
HBA & Vijlen 4 & 7 & 6 & 46 \\
Bovenste Bos & Vijlen 4-5 & 4 & 5 & 56 \\
\hline Sum & Vijlen 4-5 & $\mathbf{2 5}$ & $\mathbf{2 4}$ & $\mathbf{4 9}$ \\
\hline Mamelis & Vijlen 5-6 & 1 & 1 & 50 \\
CPL-Haccourt & Vijlen 5-6 & 20 & 1 & 5 \\
Wilkensberg & Vijlen 6 & c. 18 & c. 2 & 10 \\
\hline Sum & Vijlen 5-6 & c. $\mathbf{3 9}$ & c. $\mathbf{4}$ & c. $\mathbf{1 0}$
\end{tabular}

The means of the investigated samples of Blt. junior from interval 4 of the Vijlen Member indicate the Spyridoceramus tegulatus/Belemnitella junior Zone of the Hemmoor section in northern Germany (Fig. 2). With respect to Blt. lwowensis from interval 4 of the Vijlen Member, the slenderness and shape of the guards $(\mathrm{BI}=5.6 ; \mathrm{AV}=12.9 \%)$ are more advanced than those of specimens of the ancestral species Blt. pulchra from the uppermost Campanian to middle lower Maastrichtian of the Kronsmoor quarry section, northern Germany $(B I=6.0 ; A V=20.1 \%$ ), but are slightly more primitive than those of Blt. lwowensis from the lower upper Maastrichtian of Hemmoor $(\mathrm{BI}=5.4 ; \mathrm{AV}=10.0 \%)$. Because Blt. lwowensis first occurs $7.5 \mathrm{~m}$ above the base of the upper Maastrichtian at Hemmoor (Christensen et al., 2004), the more primitive means of the sample from interval 4 of the Vijlen Member might indicate a correlation of this unit with the lowermost c. 10-15 m of the Spyridoceramus tegulatus/ Belemnitella junior Zone at Hemmoor.

Since Blt. lwowensis disappears in the Hemmoor quarry one metre below the top of the Spyridoceramus tegulatus/ Belemnitella junior Zone (Christensen et al., 2004), the reduction in frequency of this species observed within interval 5 of the Vijlen Member may indicate correlation of this unit with the upper Spyridoceramus tegulatus/Belemnitella junior Zone. It follows from this correlation that at least the upper portion of interval 6 of the Vijlen Member may correspond already to the basal Tenuipteria argentea/Belemnitella junior Zone of the Hemmoor quarry section in northern Germany (Figs 2,4). This interpretation is in line with the small sample of Blt. junior from interval 6 of the Vijlen Member at Wilkensberg (compare Keutgen \& Van der Tuuk, 1991), where most specimens are characterised by Birkelund Indices smaller than 4.0. With respect to $B I$ and $A V$, these specimens resemble the sample of Blt. junior from the lower Tenuipteria argentea/Belemnitella junior Zone of Hemmoor described by Christensen et al. (2004).

\section{Intervals 0-3 of the Vijlen Member}

Parts of the lower portion of the Vijlen Member were exposed at Lemierserberg and in the Aachen localities Schurzelterstraße and Vaalserstraße. The belemnite record of these sections is difficult to interpret and a reliable correlation either with the late Maastrichtian Blt. junior Zone or an early Maastrichtian Belemnella zone is impossible.

With respect to Lemierserberg, the number of available belemnites $(\mathrm{N}=5)$ is too small to exclude the possibility that late Maastrichtian specimens of Belemnitella occur at that level, especially when keeping in mind that the frequency of non-reworked Belemnitella could become smaller than 5\% in some localities.

At the Aachen locality Vaalserstraße, Vijlen Member intervals 3-4 were originally exposed. While the presence of Blt. cf. lwowensis implies a correlation at least of the upper portion of the section with interval 4 or younger deposits of the Vijlen Member, i.e. the late Maastrichtian Blt. junior Zone, the record from this section of Belemnitella sp. resembling Blt. junior is more difficult to interpret. The precise level from which the specimen originated is unknown. It is either from the upper portion of interval 3 or from the lowermost portion of interval 4.

Similarly, a rostrum solidum referred to Belemnitella sp. and resembling Blt. junior is recorded from the Aachen locality Schurzelterstraße. The deposits formerly exposed here are generally considered as part of Vijlen Member interval 3, but it cannot be excluded that the base of interval 4 was also temporarily exposed. The limited information available therefore cannot be used to prove or disprove the presence of Blt. junior in interval 3 (or older deposits) of the Vijlen Member. This portion of the Vijlen Member is either of earliest late or of late early Maastrichtian age.

The base of the upper Maastrichtian is here defined by the first appearance of unequivocal Blt. junior close to the base of Vijlen Member interval 4. This interpretation is also in line with the known stratigraphic range of scaphitid ammonites (see hereafter). In addition, a sequence-stratigraphical interpretation of Vijlen Member strata also appears to favour an early Maastrichtian date for intervals 0-3. Keutgen \& Jagt (2009) identified a sea-level lowstand at the base of interval 4, which they interpreted as the sequence boundary dated at $69.4 \mathrm{Ma}$ by Vandenberghe et al. (2004). Their interpretation would imply correlation of the base of interval 4 with the base of the Maastrichtian Ma 3 sequence sensu 0gg et al. (2008), which approximates to the base of the Blt. junior Zone, i.e. the base of the classic 'upper Maastrichtian' (0gg, pers. commun.). It may be concluded that deposits of intervals 0-3 of the Vijlen Member are thus of early Maastrichtian age and belong to sequence Ma 2 (Vandenberghe et al., 2004), which probably is of Bln. cimbrica Zone age (J.G. Ogg, letter of 9 June 2009). However, an exact correlation of the FAD of Blt. junior and the Ma 3 sequence boundary has not yet been demonstrated, so that it is still 
possible that Vijlen Member intervals 0-3 are of late Maastrichtian date, if comparatively rapid sedimentation rates are assumed.

It is worth noting that Vandenberghe et al. (2004) interpreted the belemnite lag deposits at the base of the Vijlen Member as part of sequence Ma 1. According to 0gg (pers. commun.), sequence Ma 1 would roughly correspond to the $B l n$. obtusa and Bln. sumensis zones (sensu germanico). However, the frequently cited belemnite accumulations in the Beutenaken area are now known to correspond to the base of intervals 4-6 of the Vijlen Member. Older strata of this member are missing in that area. As such, these belemnite accumulations must be part of sequence Ma 3. But, because most belemnite guards collected from those accumulations belong to Bln. cf. obtusa and Bln. cf. sumensis, index taxa of sequence Ma 1 of $0 \mathrm{gg}$ et al. (2008), belemnite accumulations in the Beutenaken area may be seen as reworked relicts of the latter sequence. They demonstrate that deposits of that age were indeed present along the channel margins during deposition of most of the Vijlen Member and served as a source of remanié rostra and possibly other index taxa of early Maastrichtian age, at least in the Gulpen-Aachen area. From the base of the channel system (interval 0), belemnites have not been recorded yet. Belemnite bioclasts are common (Felder \& Bless, 1994), but, as noted above, peaks of such bioclasts do not necessarily coincide with levels rich in belemnite rostra.

In case an early Maastrichtian age of Vijlen Member interval 3 is accepted, on account of the presence of Acanthoscaphites (A.) tridens (see hereafter) and with respect to the sequencestratigraphical interpretation of Keutgen \& Jagt (2009), the Belemnella sample from the Aachen locality Schurzelterstraße may be used to determine the age of these deposits. It may be considered homogeneous with respect to standard deviation and range of variation of $\mathrm{AV}$ values, but reworking of part of the material cannot be ruled out entirely in view of deposition of interval 3 and older deposits of the Vijlen Member in a channellike structure, while transport of remanié belemnites from the channel margins to its centre has been proved (see above).

Keutgen \& Van der Tuuk (1991) referred Bln. (Pachybelemnella) specimens from the Schurzelterstraße exposures to late forms of Bln. (P.) sumensis. Indeed, the means of AV $(1.8 \pm 4.2 \%, \mathrm{~N}=34$, observed range -8.7 to $9.2 \%)$ and Lsn $(54.1 \pm 4.1 \mathrm{~mm}, \mathrm{~N}=20)$ do not differ significantly at the $5 \%$ level from the population of Bln. (P.) sumensis (f.p.) SGF 38-47 m at Hemmoor (AV: $t=1.04$, $0.5>P>0.2$ with 108 degrees of freedom; Lsn: $t=0.413, P>0.5$ with 94 degrees of freedom). The sample from Schurzelterstraße does not significantly differ from Bln. (P.) sumensis (f.p.) SGF 47-54 $\mathrm{m}$ at Hemmoor either (AV: $\mathrm{t}=1.942,0.1>>\mathrm{P}>0.05$ with 101 degrees of freedom; Lsn: $t=0.544, P>0.5$ with 87 degrees of freedom), although the probability for $\mathrm{AV}$ is very close to the $5 \%$ level. In addition, significant differences between the sample from the Schurzelterstraße and Bln. (P.) cimbrica from Hemmoor could not be detected (statistics not shown). Schulz (1979, table 6) reported 95\%-confidence intervals for the $\mathrm{AV}$ value of populations of the late form of Bln. (P.) sumensis ranging between 1.5 and $5 \%$, but defined the threshold value separating this species from Bln. (P.) cimbrica at AV $=2 \%$ (Schulz, 1979, p. 124). Populations with a mean AV value between 1.5 and $2 \%$ as in the case of the sample from the Schurzelterstraße are, thus, difficult to refer to one of the two species with certainty.

Not only does the AV value of populations decrease steadily during the late early Maastrichtian in the subgenus Bln. (Pachybelemnella), the AL value does as well (see Schulz, 1979, fig. 42) with the threshold value for AL separating Bln. (P.) sumensis from $B l n$. (P.) cimbrica being defined at $\mathrm{AL}=-10 \%$ (Schulz, 1979, p. 124). Therefore, the values for AV and AL of selected populations from the Maastricht-Aachen-Liège area (Keutgen \& Van der Tuuk, 1991; Jagt et al., 1995) are plotted and compared with those of Bln. (P.) sumensis and Bln. (P.) cimbrica from Kronsmoor and Hemmoor (Fig. 9). The means for $\mathrm{AV}$ and $\mathrm{AL}$ of the sample from the level Bm 2 at Altembroeck are typical of an early form of Bln. (P.) sumensis. In comparison, the $\mathrm{AV}$ value of the sample from the Bovenste Bos quarry is typical of an early form of Bln. (P.) sumensis as well, while the $\mathrm{AL}$ value is more advanced, pointing to a late form of this species. This discrepancy could at least partly be explained by the heterogeneity of this sample. The means of $\mathrm{AV}$ and $\mathrm{AL}$ of the

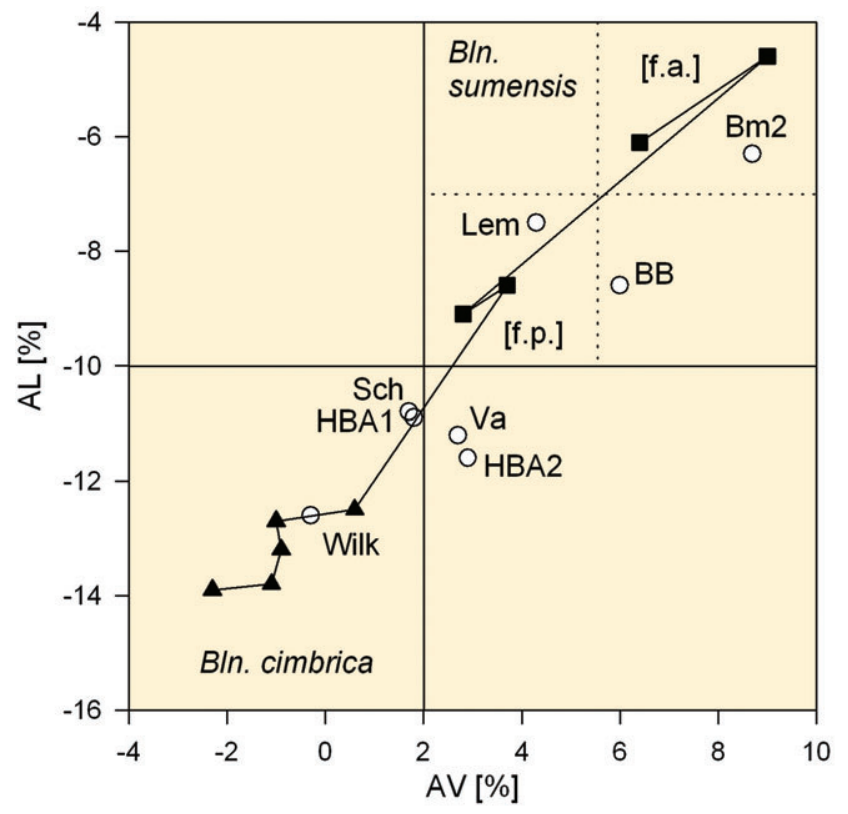

Fig. 9. Comparison of the mean $A V$ and $A L$ values of samples of the subgenus Bln. (Pachybelemnella) (Keutgen \& Van der Tuuk, 1991; Jagt et al., 1995) with the late early Maastrichtian populations from Kronsmoor and Hemmoor, northern Germany (Schulz, 1979). Localities: Lem = Lemierserberg; $S c h=$ Schurzelterstraße; Va = Vaalserstraße; Bm 2 = belemnite level Bm 2 at Altembroeck; $B B=$ Vijlen Member of the Bovenste Bos quarry, except the burrow fills in the topmost Beutenaken Member; HBA 1, HBA 2 = HansBöckler-Allee I, upper glauconitic layer and level above this; Wilk = Wilkensberg; $\mathbf{\square}=$ Bln. (P.) sumensis Jeletzky, 1949; $\Delta=$ Bln. (P.) cimbrica Birkelund, 1957. 
small sample from the Lemierserberg are both typical of $B l n$. (P.) sumensis. The samples of Bln. (Pachybelemnella) from the Aachen localities Schurzelterstraße, Vaalserstraße and HansBöckler-Allee plot close to each other (Fig. 9). With respect to their positions, they can neither be referred to a population typical of a late form of $B \ln$. (P.) sumensis nor to a population typical of Bln. (P.) cimbrica. These samples have reached a developmental stage with respect to the shape of the guards, which is transitional between both species. Finally, the sample of Bln. (Pachybelemnella) recorded by Keutgen \& Van der Tuuk (1991) from the Aachen locality Wilkensberg plots close to populations typical of $B \ln$. $(P$.$) cimbrica, indicating the presence$ of this species in the Maastricht-Aachen-Liège area. However, the sample from Wilkensberg is obviously reworked, because contemporaneous deposits in the Haccourt area have not yielded specimens of the genus Belemnella.

The question is from which level of the Vijlen Member the sample from the Wilkensberg was reworked. Because interval 4 of the Vijlen Member must be attributed to the late Maastrichtian Blt. junior Zone, this would imply reworking from older deposits, perhaps from interval 3, of the Vijlen Member.

In summary, interval 3 of the Vijlen Member may be correlated either with the early Maastrichtian late Bln. sumensis Zone or with the Bln. cimbrica Zone (sensu germanico) based on the mean values of the Belemnella sample from the Aachen locality Schurzelterstraße. This result matches the sequence-stratigraphical interpretation, which would favour a Bln. cimbrica Zone age. However, an earliest late Maastrichtian date (lower Spyridoceramus tegulatus/Belemnitella junior Zone (sensu germanico)) cannot be ruled out entirely for Vijlen Member interval 3.

\section{Scaphitid ammonite records from the Vijlen Member}

Scaphitids can be used to correlate Vijlen Member intervals 3-6 and successions in northern Germany and the United States. The early Maastrichtian age of interval 3 is corroborated by records of fairly well-preserved material of Acanthoscaphites (A.) tridens from the lower portion of the Vijlen Member as exposed at Vaalserstraße and Schurzelterstraße (Jagt et al., 1999), whereas specimens recorded from interval 4 (Altembroeck and Hans-Böckler-Allee) are fragmentary only (NK, unpubl. data) and may thus be considered reworked (Fig. 4). The documented range of $A$. (A.) tridens is Bln. lanceolata to Bln. sumensis zones (sensu germanico) (Niebuhr, 2003; Kin, 2010). However, for material from the Maastricht-Aachen-Liège area, a Bln. cimbrica Zone age has also been suggested (Jagt et al., 1992).

Acanthoscaphites (A.) tridens crosses the Campanian/ Maastrichtian boundary (as defined at Tercis les Bains), the base of the Maastrichtian being near-contemporaneous with the lower limit of the Endocostea typica inoceramid Zone, which is situated either close to the base (Niebuhr, 2003) of or within the Bln. obtusa Zone (Machalski et al., 2007). The co-occurrence of A. (A.) tridens and Bln. ex gr. sumensis/cimbrica within interval 3 of the Vijlen Member confirms the Maastrichtian age of this unit, most probably early Maastrichtian. Despite the presence of $A$. (A.) tridens, a late Maastrichtian age of Vijlen Member interval 3 cannot be ruled out entirely in view of the deposition of this and older intervals of this member in a channel-like structure, where transport of material from the channel margins into the centre may be considered to have been a significant factor, as demonstrated already for intervals 4-6. The short transport distance from the channel margins may explain the relatively good preservation of at least some of the Acanthoscaphites shells.

Equally important for supraregional correlations is $A$. (Euroscaphites) varians blaszkiewiczi, which is known from the uppermost portion of interval 5, plus interval 6. At Hemmoor (northern Germany), this taxon has been recorded from equivalents of the Bln. cimbrica Zone (i.e., upper lower Maastrichtian) to the Tenuipteria argentea/Belemnitella junior Zone (sensu germanico) (see Machalski, 2005). The commonest scaphitid in Vijlen Member intervals 4-6 is Hoploscaphites constrictus, which is long ranging (i.e., uppermost Campanian (Bln. lanceolata Zone) to lowermost Danian, sensu Machalski, 2005; Machalski et al., 2009). Two other species of stratigraphical value are $H$. tenuistriatus (Kner, 1848) and Hoploscaphites sp. (Fig. 4). The former is currently known from interval 6(?) at Mesch (southern Limburg, the Netherlands) and from interval 4 at Altembroeck. At Hemmoor, it occurs in the Bln. sumensis to Spyridoceramus tegulatus/Belemnitella junior zones (sensu germanico) (Machalski, 2005). The presence of Hoploscaphites sp., interpreted as an interspecies hybrid (Machalski et al., 2007) between the North American Jeletzkytes dorfi Landman \& Waage, 1993 and an unidentified subspecies of the endemic European lineage of $H$. constrictus, allows correlation of the lower portion of Vijlen Member interval 6 with the Hoploscaphites birkelundae Zone of the United States Western Interior. In this respect, the record of Trachybaculites columna (Morton, 1834) from interval 6 of the Vijlen Member is also important (Jagt, 2005). Records of this taxon from the Western Interior of the United States are from the zones of Hoploscaphites nicolletii and Jeletzkytes nebrascensis (Landman \& Cobban, 2003; Jagt, 2005). A closely related form, referred to as Trachybaculites sp. cf. T. columna, has been recorded from the Hoploscaphites birkelundae Zone (Fox Hills Formation) in Larimer County, Colorado (Landman \& Cobban, 2003).

\section{Conclusions}

The present study has revealed that the typically late Maastrichtian belemnite taxa Blt. junior and Blt. lwowensis occur within intervals 4-6 of the Vijlen Member, while species of the genus Belemnella have locally been found up to the base of the Lixhe Member (Van der Ham \& Van Birgelen, 1992; Felder, 1997). Nevertheless, the key sections Pesaken-Crapoel and 
Haccourt indicate that specimens of Belemnella must be considered reworked into deposits belonging to Vijlen Member intervals 4-6, because at both localities, specimens which could be referred to Bln. ex gr. sumensis/cimbrica have not been found. The origin of remanié specimens of Belemnella is unknown, but preliminary data suggest they were derived from high-energy, nearshore marine settings along the margins of the channel system which extended from Aachen to Gulpen and from Altembroeck to Lanaye. Due to its sedimentation history, it may be speculated that reworked belemnite rostra can be expected to occur within the entire Vijlen Member. With reworking being a common feature of Vijlen Member belemnites, and in consideration of the fact that without additional geochemical analyses remanié material can barely be recognised (compare Nieto et al., 2008), we refrain from subdividing the Vijlen Member by belemnitellid cephalopods.

\section{Systematic palaeontology}

\section{Terminology of the guard, measured characters and abbreviations}

Terminology and methods to describe guards of the genus Belemnitella follow Christensen (1995) and Christensen (1999, figs 9,14$)$; the shape of guards is measured as suggested by Schulz $(1979,1982)$. Abbreviations, as indicated in Fig. 10, are as follows:

Bs lateral diameter halfway between apex and protoconch (in $\mathrm{mm}$ ).

$\mathrm{Bp}$ lateral diameter at protoconch (in $\mathrm{mm}$; corresponds to LDP of Christensen).

$\mathrm{Bc}$ lateral diameter at rostrum cavum, 1/4 Ls from protoconch (in $\mathrm{mm}$ ).

Ds dorsoventral diameter halfway between apex and protoconch (in mm).

Dp dorsoventral diameter at protoconch (in mm; corresponds to DVDP of Christensen).

Dc dorsoventral diameter at rostrum cavum, $1 / 4 \mathrm{Ls}$ from protoconch (in $\mathrm{mm}$ ).

Qp Bp/Dp.

Ls length from apex to protoconch (in mm; corresponds to LAP of Christensen).

BI Birkelund Index (BI = Ls/Dp; corresponds to 'Elongation' of Schulz, 1982).

$\mathrm{AV}$ ventral aspect $(\mathrm{AV}=(\mathrm{Bs}-\mathrm{Bc}) \times 100 / \mathrm{Bp}$ in $\%)$.

$\mathrm{AL} \quad$ lateral aspect $(\mathrm{AL}=(\mathrm{Ds}-\mathrm{Dc}) \times 100 / \mathrm{Dp}$ in $\%)$.

AVs ventral aspect of rostrum solidum $(A V s=(B s-B p) \times 100 / B p$ in \%).

ALs lateral aspect of rostrum solidum $($ ALs $=(D s-D p) \times 100 / D p$ in \%).

SD Schatzky Distance, the distance (in $\mathrm{mm}$ ) between the anterior part of the protoconch and the posterior end of the ventral fissure measured along the axis of the guard.
The SD has been measured in different ways by authors (compare Schulz, 1979, p. 26). It is worth noting that the present definition differs from that used by Schulz (1979) and Keutgen \& Van der Tuuk (1991), who measured the Schatzky Distance as the distance between mid-protoconch and the posterior end of the ventral fissure. Their definition results in c. $0.5 \mathrm{~mm}$ larger values, which is the reason why some specimens of the genus Belemnella were incorrectly referred to Belemnitella ex gr. junior by Keutgen \& Van der Tuuk (1991).

AA alveolar angle, which is the dorsoventral angle (in degrees) between the walls of the alveolus measured in the median plane about 10-15 mm from the protoconch. It is worth noting that the alveolar angle changes during the ontogenetic development of the guard (Kongiel, 1962; Schulz, 1979). An inexact position of the measurement may thus result in significant differences, even within the same population (compare Schulz, 1979, p. 23).

FA fissure angle, which is the angle (in degrees) between the wall of the alveolus and the straight line connecting the intersection points of the bottom of the ventral fissure on the wall of the alveolus and the outer margin of the guard. Note that this definition is different to that of Schulz (1979).

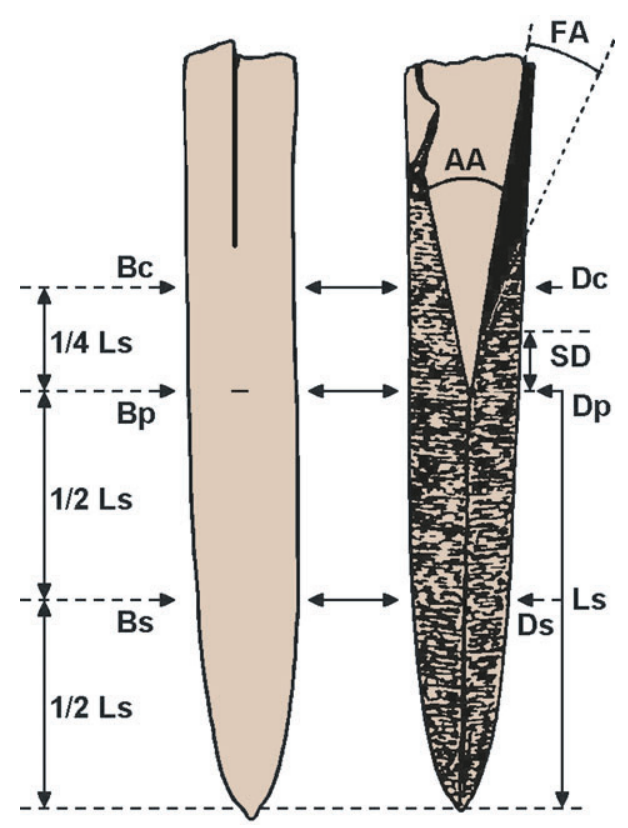

Fig. 10. Terminology of belemnite guard, ventral view and longitudinally split guard showing internal features (modified after Jagt et al., 1987); see text for abbreviations.

Linear measurements of Ls and SD were made with a ruler to an accuracy of $0.5 \mathrm{~mm}$; those of Bs, Bp, Bc, Ds, Dp, and Dc with a vernier calliper to an accuracy of $0.1 \mathrm{~mm}$. Angles were measured with a geometrical triangle to an accuracy of 1 degree.

The range of variation of the species studied was analysed using univariate and bivariate statistical methods, as described 
in Keutgen \& Jagt (1999). In the univariate analyses, estimates of the following statistics were calculated: arithmetical mean value (Mean), standard deviation (S) and coefficient of variation (CV). In addition, the observed range (OR) is recorded; $\mathrm{N}$ is the number of specimens. A linear regression analysis $(\mathrm{Dp}=\mathrm{a}+\mathrm{b} \times \mathrm{Ls}$ ) was carried out in order to study the relative growth. The estimates of the following statistical parameters were calculated: the slope (b) and the standard deviation of the slope $\left(S_{b}\right)$, the intercept on the Dp-axis $(a)$, the standard deviation of the intercept $\left(\mathrm{S}_{\mathrm{a}}\right)$, the standard deviation of the regression line $\left(S_{\mathrm{yx}}\right)$, and the correlation coefficient $(\mathrm{r})$.

The following categories have been defined by Christensen (1995) and Christensen et al. (2004) to characterise size, relative length and shape of species of Belemnitella:

Size:

- length from apex to protoconch <55 mm: small guard

- length between 55 and $65 \mathrm{~mm}$ : large guard

- length $>65 \mathrm{~mm}$ : guard very large.

Birkelund Index:

- BI <4: stout guard

- BI between 4 and 5: slender guard

- BI $>5$ : very slender guard.

Shape:

- AV and AL larger than 30\%: lanceolate guard

- AV and AL between 10 and 30\%: slightly lanceolate guard

- AV and AL between -10 and 10\%: subcylindrical guard

- AV and AL between -30 and -10\%: subconical guard

- AV and AL smaller than -30\%: conical guard.

The following categories are proposed for the characterisation of SD and FA in the genus Belemnitella:

Schatzky Distance:

- distance $<4 \mathrm{~mm}$ : very small

- distance between 4 and $7 \mathrm{~mm}$ : small

- distance between 7 and $11 \mathrm{~mm}$ : large

- distance >11 mm: very large.

Fissure angle:

- angle <25 degrees: small

- angle between 25 and 45 degrees: medium

- angle between 45 and 65 degrees: large

- angle >65 degrees: very large.

Order Belemnitida von Zittel, 1895

Suborder Belemnopseina Jeletzky, 1965

Family Belemnitellidae Pavlow, 1914

Genus Belemnitella d'Orbigny, 1840

\section{Type species}

Belemnites mucronata von Schlotheim, 1813; ICZN Opinion 1328 (1985); name no. 2979.

\section{Emended diagnosis}

See Christensen (1997).

\section{Belemnitella mucronata group}

This group includes species with small to very large, usually stout guards; fissure angle usually small to medium-sized, Schatzky Distance and alveolar angle variable.

Belemnitella cf. minor II Christensen, 1995

Fig. 11A, B.

compare

1991 Belemnitella ex gr. mucronata (Schlottheim); Keutgen \& Van der Tuuk, p. 13 (partim), pl. 1, figs 1, 2.

1995 Belemnitella minor II Christensen, p. 64, pl. 7, figs 3-10; text-figs 20A-D.

1995 Belemnitella minor III Christensen, p. 69, pl. 8, figs 1-9.

1999 Belemnitella minor II Christensen, 1995; Christensen, p.114, pl. 3, figs 1-19; pl. 4, figs 1-7 (with additional synonymy).

\section{Holotype}

NHM C43553, the original of Christensen (1995, pl. 7, figs 3-6), from Whitlingham, near Norwich (England), Paramoudra1 Chalk, by original designation.

\section{Material}

Fifty-four specimens and larger fragments (NHMM 2007 002/ 1-54) from the lower $3.5 \mathrm{~m}$ of the glauconitic layer (Vijlen Member) at Pesaken-Crapoel.

\section{Description}

Guards of Blt. cf. minor II reach a large size (Ls slightly above $60 \mathrm{~mm}$ ), are stout, but somewhat more slender than typical forms of that subspecies (mean BI c. 3.7). The relationship of Ls and $\mathrm{Dp}$ is isometric. Guards are cylindrical or slightly conical in ventral view and high conical in lateral view. Juvenile guards are more conical in ventral as well as in lateral aspect. The guards are slightly flattened over their entire length and the apex is acute or obtuse with a mucro. Vascular markings are well developed ventrally and laterally. The dorso-lateral depressions and dorso-lateral longitudinal double furrows are prominent. Some specimens are pseudogranulated ventrally and have longitudinal striae on the posterior dorsal side. For means and range of variation of internal characters (SD, AA, FA), as well as for AV, AL and BI, see Table 5 and Fig. 12.

\section{Discussion}

Belemnitella minor II differs from Blt. minor I Jeletzky, 1951a in being stouter and having a larger Schatzky Distance. Keutgen \& Jagt (1999) referred specimens from the Beutenaken Member of Slenaken to Blt. minor II. However, since their study, more populations of Blt. minor I and Blt. minor II have been described from Norfolk and Mons (southern Belgium) (see Christensen, 


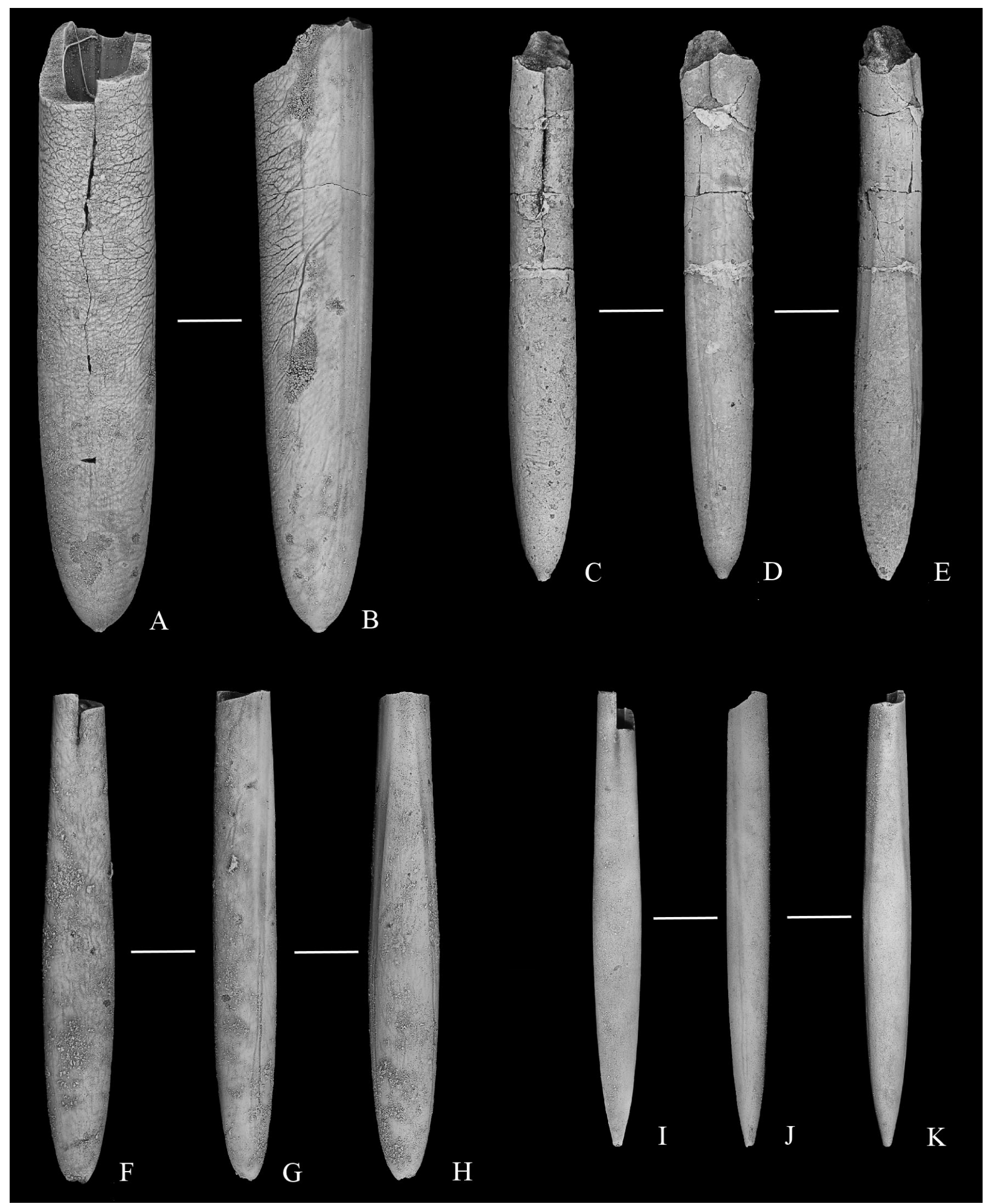

Fig. 11. Belemnitellid species from the Vijlen Member. A, B. Belemnitella cf. minor II Christensen, 1995 (NHMM 2007 002/1), Pesaken-Crapoel, lower 3.5 metres of glauconitic layer (ventral and lateral views, respectively); C-E. Belemnitella sp. (NHMM 2007 015), Vaalserstraße, interval 3 or 4 (ventral, dorsal and lateral views, respectively); F-H. Belemnella (Pachybelemnella) cf. inflata (Arkhangelsky, 1912) (NHMM 2007 005), Pesaken-Crapoel, glauconitic layer, exact level unknown (ventral, lateral and dorsal views, respectively); I-K. Belemnella (P.) cf. inflata (Arkhangelsky, 1912 ), NHMM 2007006 (ex Bi 1), Pesaken-Crapoel, c. 3.2-3.4 metres above base of glauconitic layer (ventral, lateral and dorsal views, respectively). All specimens coated with ammonium chloride prior to photography; all figures are natural size. 
Table 5. Univariate and bivariate analyses of Belemnitella $c f$. minor II Christensen, 1995 from the lower 3.5 metres of the glauconitic greensand at the Pesaken-Crapoel road section (see also Fig. 11).

\begin{tabular}{llllll}
\hline Character & N & Mean & S & CV & OR \\
\hline Ls (mm) & 49 & 46.4 & 7.6 & 16.5 & $25-61$ \\
Dp (mm) & 50 & 12.9 & 2.4 & 18.9 & $6.5-17.4$ \\
Qp & 49 & 0.98 & 0.03 & 2.99 & $0.91-1.06$ \\
BI & 49 & 3.7 & 0.3 & 7.1 & $3.1-4.3$ \\
SD (mm) & 30 & 11.7 & 2.2 & 19.2 & $7.5-17$ \\
FA (degrees) & 28 & 23.4 & 15 & 63.9 & $8-70$ \\
AA (degrees) & 29 & 19.3 & 1.3 & 6.7 & $17-22$ \\
AV (\%) & 44 & -6.1 & 4.3 & - & $-14.4-4.3$ \\
AL (\%) & 44 & -19.4 & 3.6 & - & $-27.4-(-11.2)$ \\
\hline
\end{tabular}

$\mathrm{Dp}=-0.6934+0.2906 \mathrm{Ls} ; \mathrm{N}=49 ; \mathrm{r}=0.92$;

$\mathrm{S}_{\mathrm{a}}=0.8487 ; \mathrm{S}_{\mathrm{b}}=0.018 ; \mathrm{S}_{\mathrm{yx}}=0.9655$;

$t_{a}=0.817 ; 0.5>P>0.4$ with 47 degrees of freedom.

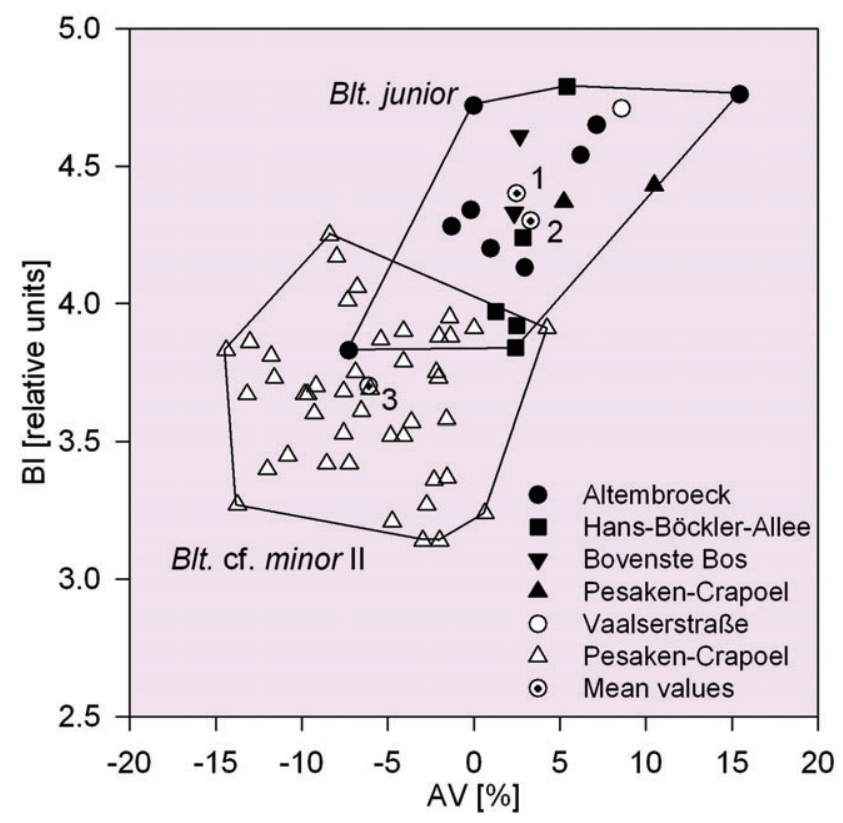

Fig. 12. Scatter plot of Belemnitella junior Nowak, 1913 (symbols $\bullet, \mathbf{\square}, \mathbf{\nabla}, \mathbf{\Delta}$ ), Belemnitella sp. from Vaalserstraße (symbol o), and remanié specimens of Belemnitella cf. minor II Christensen, 1995 from Pesaken-Crapoel (symbol $\Delta$ ). The mean values correspond to: 1 - sample of Blt. junior from 0-36 $m$ above the base of the upper Maastrichtian at Hemmoor (Christensen et al., 2004); 2 -sample of Blt. junior from the Vijlen Member; 3 -sample of Blt. cf. minor II from the Vijlen Member. AV = shape of guard in ventral view; $B I=$ Birkelund Index.

$1995,1999)$, so that the range of variation of both subspecies is yet better known. In Blt. minor I the mean Birkelund Index (BI) varies between 3.7 and 4.2 and the mean Schatzky Distance (SD) between 8 and $10.5 \mathrm{~mm}$, while in Blt. minor II the corresponding variation is 3.5 to 3.8 for the mean $\mathrm{BI}$ and 10.4 to $12.3 \mathrm{~mm}$ for the mean SD. The means of the sample from Slenaken $(\mathrm{BI}=3.7 ; \mathrm{SD}=9.4 \mathrm{~mm}$; see Keutgen \& Jagt, 1999) indicate that these specimens fall within the range of Blt. minor I. In conclusion, only Blt. minor I has yet been documented from the Beutenaken Member of the Beutenaken type area, but it cannot be excluded that the topmost Beutenaken Member locally contains Blt. minor II. In this context, the reworked belemnites of Blt. cf. minor II described here from interval 4 of the Vijlen Member at the Pesaken-Crapoel road section deserve special attention, because they co-occurred with bioclasts (Felder, 2001) and foraminifera (Hofker, 1966) typical of the Beutenaken Member. Presumably, specimens of Blt. cf. minor II were reworked from originally preserved, stratigraphically younger Beutenaken Member deposits.

Together with Blt. cf. minor II, two specimens of Belemnitella (NHMM 2007 034/1-2) have been collected, which could either represent extreme variants of $B l t$. cf. minor II or could be related to Belemnitella najdini Kongiel, 1962, a taxon known from the Beutenaken Member (Keutgen \& Jagt, 1999). These specimens, which were found 10-30 cm and 130-140 cm above the base of the Vijlen Member respectively, are slender $(\mathrm{BI}=3.9$ and 4.3 ) and are characterised by large Schatzky distances (SD $=9 \mathrm{~mm}$ ) as well as very large fissure angles (69 and 82 degrees). The large Schatzky distances favour an interpretation as Blt. cf. minor II rather than as Blt. cf. najdini.

\section{Distribution}

Christensen (1999) recorded Blt. minor II from Norfolk (Paramoudra and Sidestrand Chalk members), the Mons Basin, southern Belgium (top of the Spiennes Chalk Formation and Ciply Malogne Phosphatic (halk Formation), and from the study area. While the Paramoudra Chalk Member is of late Campanian age, the Sidestrand Chalk Member is more difficult to date. It comprises part of the Bln. lanceolata Zone, the Bln. pseudobtusa and part of the Bln. obtusa Zone (Christensen, 1995, text-fig. 3). Depending on whether the Campanian/Maastrichtian boundary as defined at Tercis les Bains is equated with the base of the Bln. obtusa Zone (Niebuhr, 2003) or with a level within this zone (Machalski et al., 2007), that boundary would have to be placed either within the upper portion of the Sidestrand Chalk Member or even at its top. As a consequence, Blt. minor II could represent an exclusively Campanian species, but at present it cannot be ruled out that the stratigraphical range of this species extended into the basal Maastrichtian. Specimens of Blt. cf. minor II collected from the basal Vijlen Member at PesakenCrapoel, the Bovenste Bos quarry and in the Beutenaken area may thus be of latest Campanian to earliest Maastrichtian age. 
Belemnitella junior Nowak, 1913

Fig. 13A-C, G, H, L, M.

*1913 Belemnitella mucronata Schlotheim sp. mut. junior Nowak, p. 398, pl. 42, figs 18, 21, 25 (non fig. 26).

1951b Belemnitella junior Nowak s. str.; Jeletzky, p. 99, pl. 2, figs 2, 6, 7; pl. 3, figs 1, 2 .

1951b Belemnitella junior Nowak var. nowaki Jeletzky, p. 109, pl. 3, fig. 3; pl. 4, figs 1, 2.

1991 Belemnitella ex gr. mucronata (Schlottheim); Keutgen \& Van der Tuuk, p. 13 (partim) (non pl. 1, figs 1, 2).

1991 Belemnitella ex gr. junior Nowak; Keutgen \& Van der Tuuk, p. 15 (partim), pl. 2, fig. 4 (non pl. 1, fig. 3; pl. 2, fig. 3).

2004 Belemnitella junior Nowak; Christensen et al., p. 38, pl. 1, figs 1-13; pl. 2, figs 1-10 (with additional synonymy).

\section{Lectotype}

The original of Nowak (1913, pl. 42, fig. 18), from Zaszkow near L'viv (western Ukraine), by subsequent designation of Jeletzky (1951b).

\section{Material}

Eleven specimens (NHMM 1997 082, 1997 083/3, 2007 008/1-3, 2007 009/1-4 and 2007 010/1-2) from Altembroeck (levels Bm 1 (3 specimens), Bm 2 (4 specimens, plus a larger fragment), Bm 3 (1 specimen), interval Gc 1-Bm 4 (1 specimen)); seven specimens (NHMM 1997 073, 2007 020-022, 2007 031/1-2 and 2007 033) from Hans-Böckler-Allee (upper glauconitic layer (5 specimens) and overlying marlstone (2 fragments)); two specimens (NHMM 2007 003-004) from Pesaken-Crapoel (glauconitic layer, 1.3-1.4 m and 2.2-2.4 $\mathrm{m}$ above base of Vijlen Member, respectively); two specimens (NHMM 2007 012/1-2) from Bovenste Bos quarry, albeit with a query (glauconitic greensand filling topmost chalkstone of Beutenaken Member), plus one (NHMM 2007 013) from the same locality (overlying marlstone of Vijlen Member); one specimen (NHMM 2007 014) from Wilkensberg.

\section{Description}

Guards large and, for representatives of the mucronata group, comparatively slender; generally subcylindrical in ventral and subconical in lateral view; slightly flattened over the entire length. Relationship between length from apex to protoconch and dorsoventral diameter at protoconch isometric (Fig. 14; Table 6). Apical end obtuse or acute with a distinct mucro; dorsolateral depressions, double furrows and vascular imprints usually well developed; guards pseudogranulated ventrally and showing longitudinal striae dorsally. For means and range of variation of internal characters (SD, AA, FA), as well as for $\mathrm{AV}$, $\mathrm{AL}$ and $\mathrm{BI}$, see Table 6 .

\section{Discussion}

Christensen et al. (2004) described Blt. junior from the upper Maastrichtian at Hemmoor and from the Maastricht-AachenLiège area, and were able to show that during the late Maastrichtian, guards of this species became stouter and more subconical. The means for AV and BI of material of Blt. junior from the Vijlen Member are closely similar to those of Hemmoor 0-36 $\mathrm{m}$ above the base of the upper Maastrichtian and these Vijlen Member specimens may therefore be referred to early forms of that species. It is worth noting that the earliest sample of Blt. junior from level Bm 1 at Altembroeck (interval 4) is characterised by means for $\mathrm{AV}$ and $\mathrm{BI}$ that are typical of this species (Table 7). The larger mean AV value of the PesakenCrapoel sample may be due to the fact that single more conical forms of Blt. junior could have been misinterpreted as Blt. cf. minor II (Fig. 12).

\section{Distribution}

Belemnitella junior is the index species of the upper Maastrichtian; earlier records from lower Maastrichtian strata in the Maastricht-Aachen-Liège area are here shown to be based on misinterpretations of the belemnite fauna. Kongiel (1962) recorded Blt. junior from the entire Maastrichtian in the Middle Vistula River valley section, central Poland; his early Maastrichtian records have to be checked carefully. Belemnitella junior is known from the upper Maastrichtian of the Netherlands, Belgium, Germany, Denmark, Poland, the Ukraine (including Crimea) and Azerbaijan.

\section{Belemnitella $s p$.}

Fig. 11C-E.

1991 Belemnitella ex gr. junior Nowak; Keutgen \& Van der Tuuk, p. 15 (partim), non pl. 1, fig. 3; pl. 2, figs 3, 4.

\section{Material}

A single specimen (NHMM 2007 015) from Vaalserstraße, plus a fragment of a rostrum solidum (NHMM 2007 016) from Schurzelterstraße.

\section{Description}

NHMM 2007015 is slightly corroded. Dorsolateral depressions and double furrows are visible and are seemingly Belemnitellalike but only traces are left of the remaining surface sculpture. Apical end slightly obtuse, with a distinct mucro. Parameters describing size, shape and internal characters are summarised in Table 8.

NHMM 2007016 is merely a rostrum solidum and, hence, critical internal characters are unknown. It is referred to the genus Belemnitella on account of its characteristic surface sculpture; dorsolateral double furrows straight and dorsolateral depressions fully developed; vascular imprints well developed 


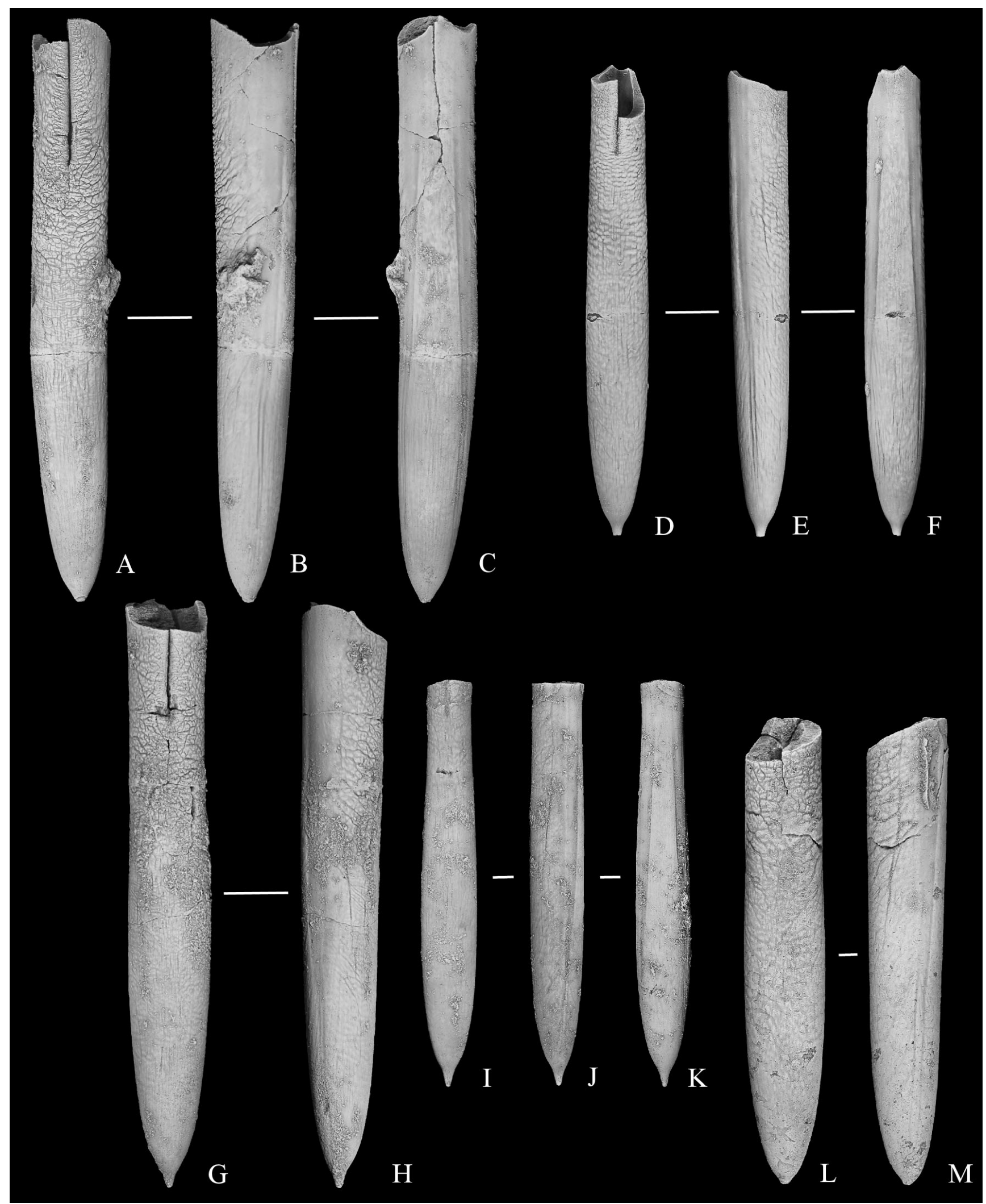

Fig. 13. Belemnitellid species from the Vijlen Member. A-C. Belemnitella junior Nowak, 1913 (NHMM 2007 009/1), Altembroeck, level Bm 2 (ventral, lateral and dorsal views, respectively); D-F. Belemnitella lwowensis Naidin, 1952 (NHMM 2007 026), CPL-Haccourt, Vijlen Member,interval 6 (ventral, lateral and dorsal views, respectively); G, H. Belemnitella junior Nowak, 1913 (NHMM 2007 008/2), Altembroeck, level Bm 1 (ventral and lateral views, respectively; I-K. Belemnitella ex gr. pulchra/lwowensis (NHMM 2007 011), Altembroeck, level GC 1-Bm 4 (ventral, lateral and dorsal views, respectively); L, M. Belemnitella junior Nowak, 1913 (NHMM 2007 003), Pesaken-Crapoel, glauconitic layer, 1.3-1.4 metres above base of Vijlen Member (ventral and lateral views, respectively). All specimens coated with ammonium chloride prior to photography; all figures are natural size. 


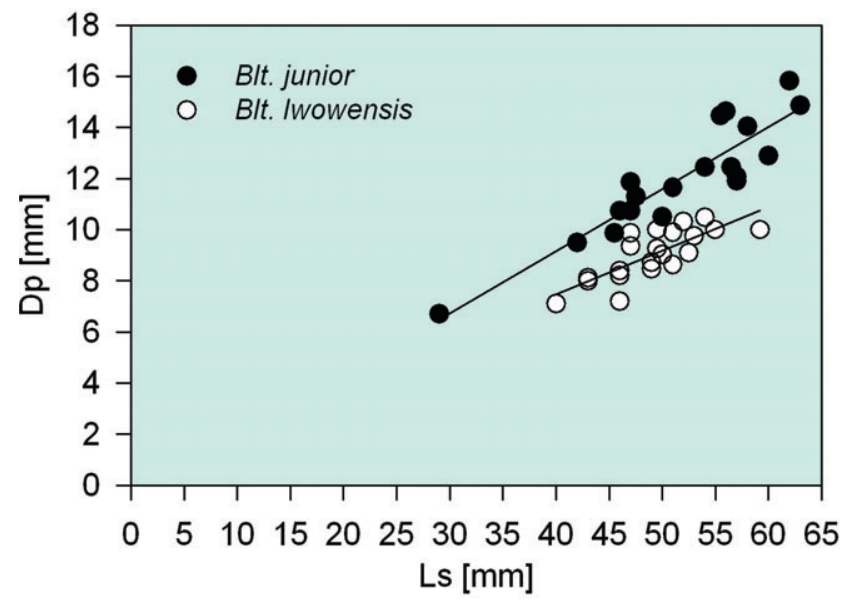

Fig. 14. Scatter plot and regression lines of Belemnitella junior Nowak, 1913 and Belemnitella Iwowensis Naidin, 1952 from the Vijlen Member; $L s=$ length from apex to protoconch; $D p=$ dorsoventral diameter at protoconch.

Table 6. Univariate and bivariate analyses of Belemnitella junior Nowak, 1913 from the Vijlen Member.

\begin{tabular}{llllll}
\hline Character & N & Mean & S & CV & OR \\
\hline Ls (mm) & 19 & 51.8 & 8.2 & 15.8 & $29-63$ \\
Dp (mm) & 20 & 11.9 & 2.2 & 18.1 & $6.7-15.8$ \\
Qp & 20 & 0.94 & 0.04 & 3.74 & $0.87-1.01$ \\
BI & 19 & 4.3 & 0.3 & 7 & $3.8-4.8$ \\
SD (mm) & 15 & 6.9 & 1.1 & 15.7 & $5-8.5$ \\
FA (degrees) & 13 & 29.7 & 9.1 & 30.7 & $18-48$ \\
AA (degrees) & 16 & 18.7 & 1.1 & 6.1 & $17-21$ \\
AV (\%) & 18 & 3.3 & 4.8 & - & $-7.3-15.5$ \\
AL (\%) & 18 & -11.5 & 3.6 & - & $-18.2-(-2.3)$ \\
\hline
\end{tabular}

$\mathrm{Dp}=-0.5739+0.2432$ Ls; $\mathrm{N}=19 ; \mathrm{r}=0.9098$;

$\mathrm{S}_{\mathrm{a}}=1.4100 ; \mathrm{S}_{\mathrm{b}}=0.0269 ; \mathrm{S}_{\mathrm{yx}}=0.9584 ;$

$t_{a}=-0.407 ; 0.7>P>0.60$ with 17 degrees of freedom.

ventrally and laterally and extend almost to apex; longitudinal striae form distinct elements ventrally and dorsally, on ventral side forming pseudogranulate sculpture anteriorly.

\section{Discussion}

NHMM 2007015 resembles Blt. junior in its shape and Birkelund Index (Fig. 12), but differs from that species in having a larger Schatzky Distance (11 mm). In comparison, Christensen et al. (2004) reported the Schatzky Distance in Blt. junior to range between 5.2 and $9.7 \mathrm{~mm}$ at Hemmoor, based on as many as thirty-three specimens. In the present study, the SD is shown to vary between 5 and $8.5 \mathrm{~mm}(\mathrm{~N}=15)$. Keutgen \& Van der Tuuk (1991) measured Schatzky Distances for Blt. junior from Haccourt, and showed them to range between 5.5 and $10 \mathrm{~mm}$ $(\mathrm{N}=8)$, while Keutgen (unpubl. data) measured values between 6 and $10 \mathrm{~mm}(\mathrm{~N}=10)$ for a sample of Blt. junior from the Nekum Member (Maastricht Formation) at the Schiepersberg quarry,
Table 7. Means of AV, AL and BI for samples of Belemnitella junior Nowak, 1913 from the Vijlen Member, in part after data supplied by Keutgen \& Van der Tuuk (1991).

\begin{tabular}{llllll}
\hline Locality & Units & N & AV (\%) & AL (\%) & BI \\
\hline Altembroeck Bm 1 & Vijlen 4 & 3 & 3.4 & -13.1 & 4.3 \\
\multicolumn{1}{c}{ Bm 2 } & Vijlen 4 & 4 & 2.0 & -10.9 & 4.4 \\
\multicolumn{1}{c}{ Bm 3 - Bm 4 } & Vijlen 4 & 3 & 2.9 & -12.9 & 4.4 \\
Pesaken-Crapoel & Vijlen 4 & 2 & 7.9 & -9.8 & 4.4 \\
HBA I glauconitic layer & Vijlen 4 & 5 & 2.9 & -12.0 & 4.2 \\
Bovenste Bos & Vijlen 4-5 & 3 & 2.5 & -9.2 & 4.3 \\
CPL-Haccourt & upper Vijlen 5 - & 21 & 2.9 & -12.6 & 4.5 \\
& Vijlen 6 & & & & \\
\hline
\end{tabular}

Cadier en Keer (the Netherlands). The twelve SD measurements in Blt. junior recorded by Jeletzky (1951b, p. 103) may be added and those of eighteen specimens from the upper Maastrichtian of the Middle Vistula River Valley, central Poland (Kongiel, 1962, table 3) as well. These range between 6.5 and $8.5 \mathrm{~mm}$ and between 5 and $8.5 \mathrm{~mm}$, respectively. Thus, as many as ninety-six measurements are available showing that SD does not exceed $10 \mathrm{~mm}$ in Blt. junior.

Christensen (1995, text-fig. 9) proposed a development from Blt. minor II to the late Maastrichtian Blt. junior. In view of the fact that Blt. minor II generally is characterised by large Schatzky Distances (mean SD > 11 mm; Christensen 1995, 1999), Belemnitella sp. from Vaalserstraße would fit into this developmental lineage. However, with respect to shape and Birkelund Index, the latter does not plot within the range of Blt. minor II, but rather within that of Blt. junior (Fig. 12).

Belemnitella sp. from Vaalserstraße also resembles stout specimens of the Belemnitella pulchra-lwowensis group in shape and slenderness but the Schatzky Distance within that group does not exceed $9 \mathrm{~mm}$ (Schulz, 1982; Christensen et al., 2004). In summary, were it not for the unusually large SD,

Table 8. Measurements of critical characters of Belemnitella sp. from the Vijlen Member (NHMM 2007 015).

\begin{tabular}{lcc}
\hline Character & NHMM 2007 015 & NHMM 2007 016 \\
\hline Ls (mm) & 50.0 & 62.0 \\
Dp (mm) & 10.6 & 14.4 \\
Bp (mm) & 9.7 & 13.8 \\
Qp & 0.91 & 0.96 \\
BI & 4.7 & 4.3 \\
SD (mm) & 11.0 & - \\
FA $\left(^{\circ}\right)$ & 28 & - \\
AA $\left({ }^{\circ}\right)$ & 18 & - \\
AV $(\%)$ & 8.6 & - \\
AL $(\%)$ & -5.2 & - \\
AVs $(\%)$ & 6.8 & -3.6 \\
ALs $(\%)$ & -6.5 & -12.1 \\
\hline
\end{tabular}


Belemnitella sp. from Vaalserstraße could be regarded as a typical representative of Blt. junior. In contrast, Belemnitella sp. from Schurzelterstraße (NHMM 2007 016) is well within the range of typical Blt. junior. However, definitive identification is impossible due to incomplete preservation.

Keutgen \& Van der Tuuk (1991) referred to several specimens of Blt. junior from the lower Maastrichtian; most of these were misdated, because the age of the deposits which yielded them was based on samples of remanié material of Belemnella. However, those authors also recorded a few specimens of Belemnitella from presumably lower Maastrichtian strata from the localities Schurzelterstraße (interval 3) and Vaalserstraße (intervals 3-4). These specimens have been restudied, with the following results. One guard (NHMM 2007 016) from Schurzelterstraße is here referred to as Belemnitella sp., a second (NHMM 2007 017) may belong to the genus Belemnella, as the Schatzky Distance is slightly smaller than $5 \mathrm{~mm}$. Of four specimens recorded from the middle portion of the Vaalserstraße section (Keutgen \& Van der Tuuk, 1991, p. 15), three (NHMM 1997 069, 1997075 and 2007 018) are referred to the genus Belemnella, the fourth (NHMM 2007 015) to Belemnitella sp. For example, NHMM 1997 075 illustrated by Keutgen \& Van der Tuuk (1991, pl. 2, fig. 3) is characterised by a Schatzky Distance of $4.5 \mathrm{~mm}$ and an alveolar angle of $16^{\circ}$, which is typical of Belemnella. NHMM 1997 069, as illustrated by Keutgen \& Van der Tuuk (1991, pl. 1, fig. 3), is more difficult to identify. Although the Schatzky Distance is in the range of 5.5 to $6.5 \mathrm{~mm}$ (i.e., typical of Belemnitella), the alveolar angle is as small as $16^{\circ}$. Ontogenetic growth stages visible in this specimen indicate allometric, rather than isometric, growth and the calculated late ontogenetic growth quotient (WQs) of 2.6 is typical of late early Maastrichtian species of the subgenus Bln. (Pachybelemnella). In addition, the weakly developed vascular imprints are more typical of Belemnella than of Belemnitella. Therefore, this specimen is best regarded as belonging to ?Belemnella sp., despite the unusually large Schatzky Distance.

\section{Distribution}

At Vaalserstraße, Belemnitella sp. was collected from the 'middle portion' of the section exposed. It is either from interval 3 or interval 4, and thus of late early Maastrichtian or earliest late Maastrichtian age. The provenance of the specimen from Schurzelterstraße is not well documented. It is here assumed to have originated from interval 3, which would thus be early Maastrichtian. However, it should be noted that under the designation 'Schurzelterstraße' several small exposures (construction pits for house numbers 460-565, accessible between 1978 and 1981) have been lumped together. At that time, the subdivision of the Vijlen Member (Felder \& Bless, 1994) was not available and hence it cannot be ruled out entirely that the base of interval 4 was actually exposed in any one of these exposures. Available data suggest that Belemnitella sp. from Schurzelterstraße and Vaalserstraße are best regarded as doubtful specimens of the Blt. junior group that are probably of early late Maastrichtian age in terms of belemnite stratigraphy, while a latest early Maastrichtian age cannot be ruled out entirely.

\section{Belemnitella langei group}

This group comprises species with generally small, slender to very slender guards; Schatzky Distances are small and fissure angles large. Christensen et al. (2004) assigned four species to this group: Blt. langei Jeletzky, 1948, Blt. najdini, Blt. pulchra and Blt. lwowensis.

Belemnitella lwowensis Naidin, 1952

Fig. 13D-F

*1952 Belemnitella nowaki lwowensis Naidin, p. 96, pl. 15, fig. 2. 1991 Belemnitella ex gr. junior Nowak; Keutgen \& Van der Tuuk, p. 15 (partim).

1991 Belemnitella pulchra Schulz; Keutgen \& Van der Tuuk, p. 14 (partim), pl. 2, fig. 2.

2004 Belemnitella lwowensis Naidin; Christensen et al., p. 46, pl. 3, figs 1-15 (with additional synonymy).

\section{Lectotype}

The original of Naidin (1952, pl. 15, fig. 2) from Sawadow near L'viv (western Ukraine), by subsequent designation of Christensen et al. (2004).

\section{Material}

Twelve specimens (NHMM 1997 083/12, 1997 083/4-8 and 2007 019/1-3) from Altembroeck (levels Bm 1 (2 specimens, plus one rostrum cavum fragment), Bm 2 (7 specimens, plus 2 fragments); six specimens (NHMM 2007 032/1-5, Sa1000 (ex J. Savelsberg Colln) from Hans-Böckler-Allee I (upper glauconitic layer (3 specimens, plus 2 rostrum cavum fragments); overlying marlstone (1 specimen)); one specimen (NHMM 2007 023) from Pesaken-Crapoel (glauconitic layer, 3.7-4 m above base of Vijlen Member (three specimens and two rostrum cavum fragments)); one specimen (NHMM 2007 024/1-4, ex Van der Tuuk Colln) from Bovenste Bos quarry (Vijlen Member marlstone); one specimen (NHMM 2007 025) from Mamelis (intervals 5-6); one specimen (NHMM 2007 029) from Wilkensberg; one specimen (NHMM 2007 026) from CPL-Haccourt. In addition, two ex situ specimens (NHMM 2007 030/1-2) from Aachen-Schneeberg have been included, both presumably from interval 4 .

\section{Description}

Guards large and very slender, slightly lanceolate to subcylindrical in ventral and subcylindrical in lateral view; flattened over their entire length. Relationship between 
length from apex to protoconch and dorsoventral diameter at protoconch isometric (Fig. 14); apical end acute or slightly obtuse with a well-defined mucro; dorsolateral depressions, double furrows and vascular imprints usually well developed. Guards pseudogranulate ventrally and showing longitudinal striae ventrally and dorsally. For means and range of variation of internal characters (SD, AA, FA) as well as for those of $\mathrm{AV}, \mathrm{AL}$ and BI see Table 9 and Fig. 15.

Table 9. Univariate and bivariate analyses of Belemnitella Iwowensis Naidin, 1952 from the Vijlen Member.

\begin{tabular}{llllll}
\hline Character & N & Mean & S & CV & OR \\
\hline Ls (mm) & 21 & 49.2 & 4.5 & 9.1 & $40-59.2$ \\
Dp (mm) & 26 & 9 & 1.1 & 12.1 & $6.9-10.9$ \\
Qp & 26 & 0.91 & 0.03 & 3.36 & $0.86-0.98$ \\
BI & 21 & 5.5 & 0.4 & 7 & $4.8-6.4$ \\
SD (mm) & 18 & 6.3 & 0.9 & 14.3 & $5-8$ \\
FA (degrees) & 15 & 55.6 & 17 & 30.7 & $28-105$ \\
AA (degrees) & 15 & 18.7 & 1.1 & 5.9 & $17-20$ \\
AV (\%) & 20 & 13.1 & 3.3 & - & $8-18.6$ \\
AL (\%) & 20 & -4.2 & 4.4 & - & $-12.4-2.5$ \\
\hline
\end{tabular}

$\mathrm{Dp}=0.6599+0.1704 \mathrm{Ls} ; \mathrm{N}=21 ; \mathrm{r}=0.7744$;

$\mathrm{S}_{\mathrm{a}}=1.5769 ; \mathrm{S}_{\mathrm{b}}=0.0319 ; \mathrm{S}_{\mathrm{yx}}=0.6531 ;$

$t_{a}=0.418 ; 0.7>P>0.6$ with 19 degrees of freedom.

\section{Discussion}

Keutgen \& Van der Tuuk (1991) referred all small and slender specimens of Belemnitella from the Vijlen Member to Blt. pulchra, because they interpreted the range of variation of this species too widely. A thorough restudy of their, as well as of additional, material has now revealed that most specimens actually should be assigned to Blt. lwowensis instead. Most of them also plot close to Blt. pulchra, but isolated specimens from Altembroeck (level Bm 1), Hans-Böckler-Allee, Bovenste Bos and Pesaken-Crapoel are characterised by AV values smaller than $10 \%$ and thus are clearly out of the range of Blt. pulchra, but within that of Blt. lwowensis (Fig. 15). Still, samples of Blt. lwowensis from interval 4 comprise a high percentage of primitive, comparatively lanceolate forms. This may be due to the fact that these represent early representatives of Blt. lwowensis. The means of AV and Lsn of our samples plot more closely to those for Blt. lwowensis than to those for Blt. pulchra (Table 10; Fig. 15). For comparison, the means of a sample of Blt. pulchra from Kronsmoor are out of the observed range of specimens here assigned to Blt. lwowensis (Fig. 15).

In addition to the specimens from Altembroeck mentioned above, two specimens of Belemnitella from that locality cannot be assigned to Blt. lwowensis due to their distinctly lanceolate shape and AV values $>25 \%$ (Fig. 13I-K; Table 11). In specimen NHMM 2007 019/4 from level Bm 1 (interval 4), the course of the ventral fissure on the guard surface is slightly deformed and this specimen might be considered pathological. The second

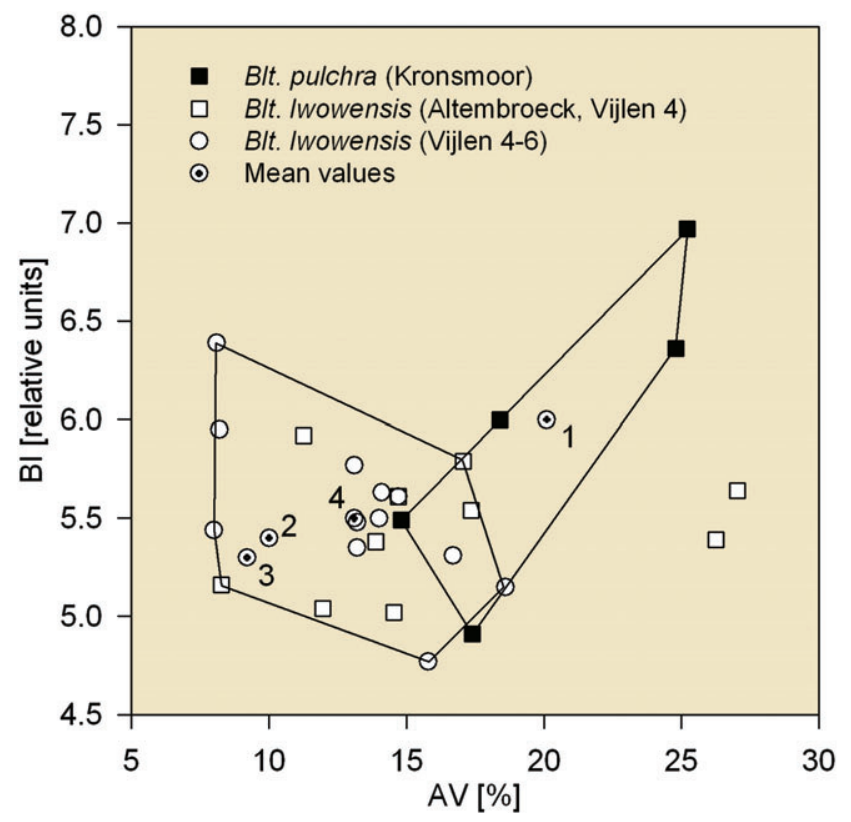

Fig. 15. Scatter plot of Belemnitella pulchra Schulz, 1982 and Belemnitella Iwowensis Naidin, 1952. The specimens of the former, as described by Schulz (1982) from Kronsmoor (symbol $\mathbf{0}$ ), are compared with those of the latter from the Vijlen Member (symbols $0, \square)$. Specimens of Blt. Iwowensis from Altembroeck (symbol $\square$ ) were separated from those collected at other localities (symbol O). The mean values correspond to: 1 - Blt. pulchra from the lower Maastrichtian at Kronsmoor; 2 - Blt. Iwowensis from the upper Maastrichtian at Hemmoor; 3 - Blt. Iwowensis from the upper Maastrichtian of Belgium and the Netherlands (see Christensen et al., 2004) and 4-Blt. Iwowensis from the Vijlen Member. AV = shape of guard in ventral view; $B I=$ Birkelund Index.

specimen NHMM 2007011 from the level between Gc 1 and Bm 4 does not show any indication of deformation. These two specimens obviously are representatives of the Blt. pulchra-lwowensis group, but it is a matter of debate whether or not these should be regarded to represent remanié Blt. pulchra, or extremely lanceolate (i.e., primitive) variants of Blt. lwowensis (Fig. 15).

Keutgen and Van der Tuuk (1991) mentioned three specimens of Blt. pulchra from the locality Vaalserstraße. These specimens have been re-investigated with the following result. Two specimens (NHMM 2007 027/1-2, ex VA5 and VA6, respectively) are indeterminable and cannot be assigned to the genus Belemnitella with certainty. The third specimen (NHMM 2007 028, ex VA 200) from the middle portion of the section exposed represents a larger fragment of a rostrum cavum characterised

Table 10. Means of AV and BI for samples of Belemnitella lwowensis Naidin, 1952 from the Vijlen Member.

\begin{tabular}{lllll}
\hline Locality & Units & N & AV (\%) & BI \\
\hline Altembroeck Bm 1 & Vijlen 4 & 2 & 11.1 & 5.3 \\
Bm 2 & Vijlen 4 & 6 & 14.5 & 5.5 \\
Hans-Böckler-Allee & Vijlen 4 & 4 & 12.0 & 5.7 \\
Bovenste Bos & Vijlen 4-5 & 3 & 13.6 & 5.7 \\
\hline
\end{tabular}


Table 11. Measurements of critical characters of Belemnitella ex gr. pulchra/Lwowensis (NHMM 2007 019/4, NHMM 2007 011) and Belemnitella cf. Iwowensis (NHMM 2007 028) from the Vijlen Member.

\begin{tabular}{llll}
\hline Character & NHMM 2007 028 & NHMM 2007 019/4 & NHMM2007 011 \\
\hline Ls (mm) & - & 49 & 43.5 \\
Dp (mm) & 7.1 & 7.62 & 8.07 \\
Bp (mm) & 6.4 & 6.77 & 7.16 \\
Qp & 0.9 & 0.89 & 0.89 \\
BI & - & 5.6 & 5.4 \\
SD (mm) & 6 & - & - \\
FA $\left({ }^{\circ}\right)$ & 33 & - & - \\
AA $\left({ }^{\circ}\right)$ & 22 & - & - \\
AV $(\%)$ & - & 27 & 26.3 \\
AL $(\%)$ & - & 8.9 & 6.1 \\
AVs $(\%)$ & - & 18.8 & 17 \\
ALs $(\%)$ & - & 3.2 & 0 \\
\hline
\end{tabular}

by a course of the ventral fissure that is typical of the Blt. pulchra-lwowensis group (Table 11). Nevertheless, the fissure angle is comparatively small, within the range of Blt. lwowensis and out of the range of variation of Blt. pulchra documented for the Kronsmoor material (c. 40-125; compare Schulz, 1982, fig. 5), but the four specimens studied by Schulz may not have been sufficient to cover the range of variation of this species. The estimated shape and Birkelund Index of NHMM 2007028 are within the range of variation of both Blt. pulchra and Blt. lwowensis. The specimen is here referred to as Belemnitella cf. lwowensis, because belemnite specimens typical of the interval upper Bln. lanceolata to middle Bln. sumensis zones (topmost Campanian to middle lower Maastrichtian), which is the known stratigraphic range of Blt. pulchra, have not been identified at the locality Vaalserstraße.

\section{Distribution}

To date, Belemnitella lwowensis is known from the upper Maastrichtian of Belgium, the Netherlands, Germany, Denmark(?), central Poland and the Ukraine. In interval 4 of the Vijlen Member of the Maastricht-Aachen-Liège area, Blt. lwowensis is almost as common as Blt. junior, whereas higher in the section, its frequency is reduced to about $10 \%$.

\section{Acknowledgements}

For assistance in various ways, we thank all fellow members of the Working Group Beutenaken and Vijlen members, plus B.W.M. van Bakel, W.K. Christensen (deceased), W.M. Felder (deceased), H. Knoll, J.G. Ogg, F.Schmid-Wallis, A.S. Schulp and M.-G. Schulz (deceased). For pertinent comments on an earlier version of the typescript we thank C.J. Wood and H.B. Vonhof.

\section{References}

Albers, H.-J. \& Felder, W.M., 1979. Litho-, Biostratigraphie und Palökologie der Oberkreide und des Alttertiärs (Präobersanton-Dan/Paläozän) von AachenSüdlimburg (Niederlande, Deutschland, Belgien. In: Wiedmann, J. (ed.): Aspekte der Kreide Europas. International Union of Geological Sciences A6: 47-84.

Arkhangelsky, A.D., 1912. Verkhnemelovyya otlozheniya vostoka evropejskoy rossii. Materialy dlja Geologii Rossii 25: xxv + 1-631, 10 pls.

Bayle, E., 1878. Fossils principaux der terrains de la France. Explication de la Carte Géologique de la France 4(1), Atlas, 79 plates.

Birkelund, T., 1957. Upper Cretaceous belemnites from Denmark. Biologiske Skrifter fra det Kongelige Danske Videnskabernes Selskab 9: 1-69, 6 pls.

Breddin, H., Brühl, H. \& Dieler, H., 1963. Das Blatt Aachen-Nordwest der praktisch-geologischen Grundkarte 1:50 000 des Aachener Stadtgebietes. Geologische Mitteilungen 1: 251-428.

Christensen, W.K., 1994. Upper Cretaceous belemnites from Lonzée (SE Belgium) and their stratigraphical significance. Bulletin de l'Institut royal des Sciences naturelles de Belgique, Sciences de la Terre 64: 151-158, 1 pl.

Christensen, W.K., 1995. Belemnitella from the Upper Campanian and Lower Maastrichtian Chalk of Norfolk, England. Special Papers in Palaeontology 51: $1-84,9$ pls.

Christensen, W.K., 1996. A review of the Upper Campanian and Maastrichtian belemnite biostratigraphy of Europe. Cretaceous Research 17: 751-766.

Christensen, W.K., 1997. The Late Cretaceous belemnite family Belemnitellidae: taxonomy and evolutionary history. Bulletin of the Geological Society of Denmark 44: 59-88, 2 pls.

Christensen, W.K., 1999. Upper Campanian and Lower Maastrichtian belemnites from the Mons Basin, Belgium. Bulletin de l'Institut royal des Sciences naturelles de Belgique, Sciences de la Terre 69: 97-131, 4 pls.

Christensen, W.K., Schmid, F. \& Schulz, M.-G., 2004. Belemnitella from the Upper Maastrichtian of Hemmoor, Northwest Germany. Geologisches Jahrbuch A157: 23-67, 3 pls.

d'Orbigny, A.D., 1840-1842. Paléontologie française; Terrains Crétacés, 1. Céphalopodes. Paris (Masson): 1-120 (1840); 121-430 (1841); 431-662 (1842), $148+3$ pls.

Doyle, P. \& Macdonald, D.I.M., 1993. Belemnite battlefields. Lethaia 26: 65-80.

Ebensberger, H., 1962. Stratigraphische und mikropaläontologische Untersuchungen in der Aachener Oberkreide, besonders der Maastricht-Stufe. Palaeontographica A120: ii +1-120, 12 pls.

Elorza, J., Garcia-Garmilla, F., \& Jagt, J.W.M., 1997. Diagenesis-related differences in isotopic and elemental composition of late Campanian and early Maastrichtian inoceramids and belemnites from NE Belgium: palaeoenvironmental implications. Geologie en Mijnbouw 75: 349-360.

Felder, P.J., 1997. The Vijlen Chalk Member (Maastrichtian, Late Cretaceous) in the Meuse-Rhine Euregion. Annales de la Société géologique de Belgique 119 (1996): 119-133.

Felder, P.J., 2001. Bioklasten-stratigrafie of ecozonatie voor het krijt (sic) (Santoniaan-Campaniaan-Maastrichtiaan) van Zuid-Limburg en oostelijk België. Memoirs of the Geological Survey of Belgium 47: 1-141.

Felder, P.J. \& Bless, M.J.M., 1994. The Vijlen Chalk (early Early to early Late Maastrichtian) in its type area around Vijlen and Mamelis (southern Limburg, The Netherlands). Annales de la Société géologique de Belgique 116: 61-85. 
Felder, W.M., 1975a. Lithostratigraphische Gliederung der Oberen Kreide in SüdLimburg (Niederlande) und den Nachbargebieten. Erster Teil: Der Raum westlich der Maas, Typusgebiet des 'Maastricht'. Publicaties van het Natuurhistorisch Genootschap in Limburg 24(1974): 1-43.

Felder, W.M., 1975b. Lithostratigrafie van het Boven-Krijt en het Dano-Montien in Zuid-Limburg en het aangrenzende gebied. In: Zagwijn, W.H. \& Van Staalduinen, C.J. (eds): Toelichting bij geologische overzichtskaarten van Nederland. Haarlem (Rijks Geologische Dienst): 63-72.

Goldfuss, A., 1826-1844. Petrefacta Germaniae tam ea, quae in museo universitatis regiae Borussicae Fridericiae Wilhelmiae Rhenanae servantur quam alia quae cunque in museis hoeninghausiano, muensteriano aliisque extant, iconibus et descriptionibus illustrata. Abbildungen und Beschreibung der Petrefacten Deutschlands und der angränzenden Länder, unter Mitwirkung des Herrn Grafen Georg zu Münster. Düsseldorf (Arnz \& Co.), viii + 1-76, pls 1-25 (1826); 77-164, pls 26-50 (1829); 165-240, pls 51-71 (1831); 241-252 (1833); 1-68, pls 72-96 (1833); 69-140, pls 97-121 (1836); 141-224, pls $122-146$ (1840); 225-312, pls 147-165 (1837); iv + 1-128, pls 166-200 (1844).

Hiltermann, H. \& Koch, W., 1950: Taxonomie und Vertikalverbreitung von Bolivinoides-Arten im Senon Nordwestdeutschlands. Geologisches Jahrbuch 64: 595-632.

Hofker, J., 1966. Maestrichtian, Danian and Paleocene Foraminifera. The Foraminifera of the type Maestrichtian in South Limburg, Netherlands, together with the Foraminifera of the underlying Gulpen Chalk and the overlying calcareous sediments; the Foraminifera of the Dansk Chalk and the overlying Greensands and Clays as found in Denmark. Palaeontographica, Supplement A10: ii + 1-376, 86 pls.

Jäger, M., 2004. Serpulidae und Spirorbidae (Polychaeta sedentaria) (sic) aus dem Campan und Maastricht von Norddeutschland, den Niederlanden, Belgien und angrenzenden Gebieten. Geologisches Jahrbuch A157: 121-249, 10 pls.

Jagt, J.W.M., 1999a. Late Cretaceous-Early Palaeogene echinoderms and the K/T boundary in the southeast Netherlands and northeast Belgium - Part 1. Introduction and stratigraphy. Scripta Geologica 116: 1-57.

Jagt, J.W.M., 1999b. Late Cretaceous-Early Palaeogene echinoderms and the K/T boundary in the southeast Netherlands and northeast Belgium - Part 2. Crinoids. Scripta Geologica 116: 59-255.

Jagt, J.W.M., 2005. Stratigraphic ranges of mosasaurs in Belgium and the Netherlands (Late Cretaceous) and cephalopod-based correlations with North America. Netherlands Journal of Geosciences 84: 283-301.

Jagt, J.W.M., Deckers, M., Dhondt, A.V., Dortangs, R.W., Felder, P.J., Felder, W.M., Jäger, M., Keutgen, N., Kuypers, M., Michels, G., Reynders, J., Simon, E., Van der Ham, R., Van Knippenberg, P. \& Van Neer, R., 1995. Preliminary report of field work at Altembroeck (NE Belgium, early Maastrichtian) by the Working Group Beutenaken/Vijlen Members. Service Géologique de Belgique, Professional Paper 1995/1 (276): 1-20.

Jagt, J.W.M., Felder, P.J. \& Meessen, J.P.M.Th., 1987. Het Boven-Campanien in Zuid-Limburg (Nederland) en Noordoost België. Natuurhistorisch Maandblad 76: 94-110.

Jagt, J.W.M. \& Kennedy, W.J., 1989. Acanthoscaphites varians (Łopuski, 1911) (Ammonoidea) from the Upper Maastrichtian of Haccourt, NE Belgium. Geologie en Mijnbouw 68: 237-240.
Jagt, J.W.M., Kennedy, W.J. \& Burnett, J., 1992. Acanthoscaphites tridens (Kner, 1848) (Ammonoidea) from the Vijlen Member (Lower Maastrichtian) of Gulpen, Limburg, the Netherlands. Geologie en Mijnbouw 71: 15-21.

Jagt, J.W.M., Kennedy, W.J. \& Machalski, M., 1999. Giant scaphitid ammonites from the Maastrichtian of Europe. Bulletin de l'Institut royal des Sciences naturelles de Belgique, Sciences de la Terre 69: 133-154, 8 pls.

Jeletzky, J.A., 1948. Zur Kenntnis der Oberkreide der Dnjepr-Donetz-Senke und zum Vergleich der russischen borealen Oberkreide mit derjenigen Polens und Nordwesteuropas. Geologiska Föreningens i Stockholm Förhandlingar 70: 583-602.

Jeletzky, J.A., 1949. Über den taxonomischen Wert einiger morphologischer Elemente des Rostrums der belemnitellenartigen Formen (Familie Belemnitellidae Pavlow, 1913), sowie über die Gattung Belemnella (Nowak, 1913, subg.) Jeletzky, 1941, ihre Phylogenie und einige Vertreter. Neues Jahrbuch für Mineralogie, Geologie und Paläontologie, B9: 257-287.

Jeletzky, J.A., 1951a. The place of the Trimingham and Norwich Chalk in the Campanian-Maestrichtian succession. Geological Magazine 88: 197-208.

Jeletzky, J.A., 1951b. Die Stratigraphie und Belemnitenfauna des Obercampan und Maastricht Westfalens, Nordwestdeutschlands und Dänemarks, sowie einige allgemeine Gliederungs-Probleme der jüngeren borealen Oberkreide Eurasiens. Beihefte zum Geologischen Jahrbuch 1: 1-142, 7 pls.

Jeletzky, J.A., 1965. Taxonomy and phylogeny of fossil Coleoidea (= Dibranchiata). Geological Survey of Canada, Paper 65-2 (42): 72-76.

Keutgen, N., 1996. Biostratigraphie, Paläoökologie und Invertebratenfauna des Untermaastricht von Aachen (Westdeutschland) und angrenzenden Gebieten (Südostniederlande, Nordostbelgien). Aachen (Shaker Verlag): iv + 213 pp.

Keutgen, N., 1997. Belemnella (Belemnella) cf. praearkhangelskii Naidin, 1964 from the Vijlen Member at Altembroeck (NE Belgium, Early Maastrichtian). Geologie en Mijnbouw 75: 341-347.

Keutgen, N. \& Jagt, J.W.M., 1999. Late Campanian belemnite faunas from LiègeLimburg (NE Belgium, SE Netherlands). Geological Survey of Belgium, Professional Paper 1998/2 (287): 1-31.

Keutgen, N. \& Jagt, J.W.M., 2009. Correlation of Maastrichtian strata in the southeast Netherlands and adjacent regions, northern Germany, northern Spain and the USA. Byulleten' Moskovskogo Obshchestva Ispytatelej Prirody, Otdel Geologicheskii 84: 71-77.

Keutgen, N. \& Van der Tuuk, L.A., 1991. Belemnites from the Lower Maastrichtian of Limburg, Aachen and Liège. Mededelingen van de Rijks Geologische Dienst 44 (1990): 1-39, 4 pls.

Kin, A., 2010. Early Maastrichtian ammonites and nautiloids from Hrebenne, southeast Poland, and phenotypic plasticity of Acanthoscaphites tridens (Kner, 1848). Cretaceous Research 31: 27-60.

Kner, $\boldsymbol{R}_{\text {., }}$ 1848. Versteinerungen des Kreidemergels von Lemberg und seiner Umgebung. W. Haidinger's naturwissenschaftliche Abhandlungen 3: 1-42, 5 pls.

Koch, W., 1977. Stratigraphie der Oberkreide in Nordwestdeutschland (Pompeckjsche Schwelle), Teil 2: Biostratigraphie der Oberkreide und Taxonomie von Foraminiferen. Geologisches Jahrbuch A38: 11-123.

Kongiel, R., 1962. On belemnites from Maastrichtian, Campanian and Santonian sediments in the Middle Vistula Valley (Central Poland). Prace Muzeum Ziemi 5: 3-140, 21 pls. 
Lambert, J., 1911. Description des Échinides crétacés de la Belgique principalement de ceux conservés au Musée royal de Bruxelles - II. Échinides de l'étage Sénonien. Mémoires du Musée royal d'Histoire naturelle de Belgique 4 (1910): 1-78, 3 pls.

Landman, N.H. \& Cobban, W.A., 2003. Ammonites from the Upper Part of the Pierre Shale and Fox Hills Formation of Colorado. American Museum Novitates 3388: 1-45.

Landman, N.H. \& Waage, K.M., 1993. Scaphitid ammonites of the Upper Cretaceous (Maastrichtian) Fox Hills Formation in South Dakota and Wyoming. Bulletin of the American Museum of Natural History 215: 1-257.

Machalski, M., 2005. Late Maastrichtian and earliest Danian scaphitid ammonites from central Europe: taxonomy, evolution, and extinction. Acta Palaeontologica Polonica 50: 653-696.

Machalski, M., Jagt, J.W.M., Heinberg, C., Landman, N.H. \& Håkansson, E., 2009. Dańskie amonity - obecny stan wiedzy i perspektywy badań. Przegląd Geologiczny 57: 486-493.

Machalski, M., Jagt, J.W.M., Landman, N.H. \& Motchurova-Dekova, N., 2007. The highest records of North American scaphitid ammonites in the European Maastrichtian (Upper Cretaceous) and their stratigraphic implications. Acta Geologica Polonica 57: 169-185.

Marsson, T., 1878. Die Foraminiferen der weissen Schreibkreide der Insel Rügen. Mittheilungen des naturwissenschaftlichen Vereins für Neu-Vorpommern und Rügen in Greifswald 10: 115-196, 5 pls.

Morton, S.G., 1834. Synopsis of the organic remains of the Cretaceous Group of the United States. Philadelphia: Key and Biddle, $88 \mathrm{pp}$.

Naidin, D.P., 1952. Verkhnemelovye belemnity zapadnoj Ukrainy. Trudy Moskovskogo Geologo-Razvedochnogo Instituta imemi S. Ordzhinikidze 27: 1-126, 21 pls.

Naidin, D.P., 1964. Verkhnemelovye belemnitelly i belemnelly Russkoj platformy i nekotorykh sopredel'nykh oblastej. Byulleten' Moskovskogo Obshchestva Ispytatelej Prirody, Otdel Geologicheskii 39: 85-97, 2 pls.

Niebuhr, B., 2003. Late Campanian and Early Maastrichtian ammonites from the white chalk of Kronsmoor (northern Germany) - taxonomy and stratigraphy. Acta Geologica Polonica 53: 257-281, 7 pls.

Nieto, L.M., Ruiz-Ortiz, P.A., Rey, J., \& Benito, M.I., 2008. Strontium-isotope stratigraphy as a constraint on the age of condensed levels: examples from the Jurassic of the Subbetic Zone (southern Spain). Sedimentology 55: 1-29.

Nowak, J., 1913. Untersuchungen über die Cephalopoden der oberen Kreide in Polen. III. Teil. Bulletin international de l'Académie des Sciences de Cracovie, Classe des Sciences mathématiques et naturelles, B1913: 335-415, pls 40-45.

Odin, G.S. \& Lamaurelle, M.A., 2001. The global Campanian-Maastrichtian stage boundary. Episodes 24 (4): 229-238.

Ogg, J.G., Ogg, G. \& Gradstein, F.M., 2008. The Concise Geologic Time Scale. Cambridge University Press, Cambridge, 184 pp.

Pavlow, A.P., 1914. Yurskie i nizhnemelovye Cephalopoda severnoi Sibiri. Imperatovski Akademii Nauk, Zapiski Seriia 8, Fizino-mathematicheskii Otdel 21 (1913): 1-68, 18 pls.

Robaszynski, F., Bless, M.J.M., Felder, P.J., Foucher, J.-C., Legoux, O., Manivit, H., Meessen, J.P.M.T. \& Van der Tuuk, L.A., 1985. The Campanian-Maastrichtian boundary in the chalky facies close to the type-Maastrichtian area. Bulletin des Centres de Recherches et d'Exploration-Production d'Elf-Aquitaine 9: 1-113, 22 pls.
Robaszynski, F., Dhondt, A.V. \& Jagt, J.W.M., 2002. Cretaceous lithostratigraphic units (Belgium). In: Bultynck, P. \& Dejonghe, L. (eds): Guide to a revised lithostratigraphic scale of Belgium. Geologica Belgica 4(2001): 121-134.

Roemer, F.A., 1840-1841. Die Versteinerungen des norddeutschen Kreidegebirges. Hannover (Hahn'sche Hofbuchhandlung): 1-48 (1840), 49-145 (1841).

Schulz, M.-G., 1979. Morphometrisch-variationsstatistische Untersuchungen zur Phylogenie der Belemniten-Gattung Belemnella im Untermaastricht NWEuropas. Geologisches Jahrbuch A47: 3-157, 12 pls.

Schulz, M.-G., 1982. Erster Nachweis der Belemnitengattung Belemnitella (B. pulchra n. sp.) im mittleren Untermaastricht NW-Deutschlands. Geologisches Jahrbuch A61: 279-293, 1 pl.

Schulz, M.-G., 1985. Die Evolution der Echiniden-Gattung Galerites im Campan und Maastricht Norddeutschlands. Geologisches Jahrbuch A80: 3-93, 15 pls.

Sowerby, J., 1817. The Mineral Conchology of Great Britain; or coloured figures and descriptions of those remains of testaceous animals or shells, which have been preserved at various times and depths in the area, 2. London (The author): pls 151-186.

Van der Ham, R. \& Van Birgelen, M., 1992. Zeeëgels uit het Maastrichtien van de Schneeberg en omgeving (Aken, Duitsland). Natuurhistorisch Maandblad 81: 139-153, 4 pls.

Vandenberghe, N., Van Simaeys, S., Steurbaut, E., Jagt, J.W.M. \& Felder, P.J., 2004. Stratigraphic architecture of the Upper Cretaceous and Cenozoic along the southern border of the North Sea Basin in Belgium. Netherlands Journal of Geosciences 83: 155-171.

Visser, A.M., 1951. Monograph on the foraminifera of the type-locality of the Maestrichtian (South-Limburg, the Netherlands). Leidse Geologische Mededelingen 16 (1950): 197-359, 11 pls.

Von Hagenow, F., 1840. Monographie der Rügen'schen Kreideversteinerungen. Abtheilung II. Radiarien und Annulaten, nebst Nachträgen zur I. Abtheilung. Neues Jahrbuch für Mineralogie, Geognosie, Geologie und Petrefaktenkunde 1840: 621-672, pl. 9.

Von Schlotheim, E.F., 1813. Beiträge zur Naturgeschichte der Versteinerungen in geognostischer Hinsicht. In: Leonhard, C.C. (ed.): Leonhard's Taschenbuch für die gesammte Mineralogie mit Hinsicht auf die neuesten Entdeckungen (1) 7: 1-134, 4 pls.

Von Zittel, K.A., 1895. Grundzüge der Palaeontologie (Palaeozoologie). München/Leipzig (R. Oldenburg): vii + 971 pp. 